\title{
From the Geomorphic Process to Basin Architecture: Anatomy of the Infill of an Alluvial-Lacustrine System in Southern Spain
}

\author{
Maria L. Calvache ${ }^{1}$, Juan Fernández² , Fernando García-García ${ }^{3}$, Jesús M. Soria ${ }^{4}$, César Viseras ${ }^{*}, 2$ \\ ${ }^{I}$ Departamento de Geodinámica, Facultad de Ciencias, Universidad de Granada, Campus de Fuentenueva, 18071 \\ Granada, Spain \\ ${ }^{2}$ Departamento de Estratigrafía y Paleontología, Facultad de Ciencias, Universidad de Granada, Campus de \\ Fuentenueva, 18071 Granada, Spain \\ ${ }^{3}$ Departamento de Geología, Facultad de Ciencias Experimentales, Universidad de Jaén, 23071 Jaén, Spain \\ ${ }^{4}$ Departamento de Ciencias de la Tierra y del Medio Ambiente, Universidad de Alicante, 3080, Alicante, Spain
}

\begin{abstract}
The heavy rains in the winter of 2009-2010 in Spain activated all the sediment-feeder systems of a small reservoir built in the 1970s north of the Sierra de Almijara (province of Granada). The intensity of this activity has aided in recognizing a series of geomorphic features allowing the re-interpretation of previous data on the subsoil obtained from Ground Penetrating Radar (GPR) and sedimentological analysis involving the study of a series of shallow trenches dug in various parts of the basin.

The unequal influence of three feeder systems in the process of silting up this small artificial lake has been noted. The main contributor is the longitudinal axial drainage system, which is building up a huge delta whose progradation and aggradation dynamics are strongly influenced by the obstruction of a transverse delta fan on a highly erodible source area comprising Tertiary detrital sediments. Far less important in the construction of the stratigraphic architecture are the transverse fans lying against the Palaeozoic to Triassic metamorphic basement.

The most notable geomorphological change over the last 35 years has been in the longitudinal axial system. Over a period of only eight years (1977-1984), it morphed from a coarse-grained braided fluvial system with a single channel in which longitudinal bars and thalwegs constantly changed position with every flood to a multichannel anastomosed system characterized by interwoven narrow, sinuous channels. Many of these channels are only covered during floods, and they are separated by heavily vegetated islands that act as traps for the overbank deposits.

The difference in soil uses in the different parts of the basin also plays an important role, causing the progradation rate of the deltas to range widely, from 0 all the way to $100 \mathrm{~m} \mathrm{yr}^{-1}$.

This study reveals that in countries of the Mediterranean region torrential rains, the scanty vegetation cover, and the alteration of the longitudinal profile of dammed rivers interact causing extreme siltation of reservoirs. Under these situations it is extremely important to study the dynamics of mass movement in the parts of the basin with different lithology to carry out effective plans of management of the reservoir and to minimize the possibility of environmental and economic negative impacts.
\end{abstract}

Keywords: Anastomosed, braided, geomorphology, GPR, siltation, Spain, stratigraphic architecture.

\section{INTRODUCTION AND AIMS}

In sedimentological studies aimed at reconstruction of the stratigraphic architecture of sedimentary basins, most of the interpretation of the sedimentary facies in terms of processes tends to be based on the application of the Actualism principle, observing the same processes and outcomes in active examples in the present $[1,2]$. This is even applicable to Quaternary systems since the observation span of the scientist is not usually long enough to directly recognize the construction dynamics of stratigraphic architecture.

*Address correspondence to this author at the Departamento de Estratigrafía y Paleontología, Facultad de Ciencias, Universidad de Granada, Campus de Fuentenueva, 18071 Granada, Spain; Fax: +3458248528;

E-mail: viseras@ugr.es
When reservoirs are located in mountainous regions and have small drainage areas, sediment yield may be up to two orders of magnitude higher than in lowlands and approximately one order higher than larger regions of mixed relief $[3,4]$. Although on average the storage capacity of reservoirs in the world diminishes by $1 \% \mathrm{yr}^{-1}$, the problem is even more serious where reservoirs have been built in alluvial basins in the Mediterranean region. Frequent droughts (and the consequent effect on ground cover) together with periodic torrential rainfall lead to heavy erosion and therefore increased sediment supply to these artificial lakes. Moreover, inappropriate soil use by humans also produces significant changes in riverine sediment supply, leading to reservoirs with similar physiographic and land cover traits evolving quite significant differences over their lifespan, as described in numerous examples [5-9]. 
Most papers on dams effects emphasize the geomorphic and ecological effects downstream of dams [10-15] and only a few of recent papers focus on sedimentation behind dams. This paper describes the dynamics of sedimentation behind of a dam in a silted reservoir [16].

A small reservoir was built in Southern Spain (Alhama de Granada) in 1974, with the double aim of flood control and water storage (initial capacity of $402,000 \mathrm{~m}^{3}$ ) (Fig. 1). The basin draining into this artificial lake is the catchment for some $69 \mathrm{~km}^{2}$ of steeply sloped mountainous region in Sierra de Almijara. A scant three decades later, the lake's storage capacity has dropped by $80 \%$, the surface area by $66 \%$, and the perimeter by $64 \%$ (Fig. 2 ).

In this work, we present an analysis of this example combining geophysical subsoil data, shallow-trench facies analyses, and geomorphological features to reconstruct the construction dynamics of this alluvial-lacustrine basin at extremely high resolution. The heavy rains in this region in the winter of 2009-2010 have activated all the alluvial systems in the basin. This has allowed us to compare the geomorphological processes with the sedimentological and geophysical data (Fig. 3). It is hoped that the results of this research will be a reference source for the undertaking of corrective measures not only in this case, but also for many others in which rapid silting of closed or semi-closed natural or artificial reservoirs is taking place.

\section{GEOLOGICAL CONTEXT AND SPECIAL FEATURES OF THE STUDY AREA}

This study develops in a small reservoir that lies on the main course of the Alhama River drainage basin, which flows northwards from the Sierra de Almijara, some $60 \mathrm{~km}$ southwest of Granada city (S. Spain) (Fig. 1). The reservoir catchment area covers $69.3 \mathrm{~km}^{2}$ with a circumference of $41.6 \mathrm{~km}$. The upper boundary of the dam is at $880 \mathrm{~m}$ asl; the drainage basin has a maximum elevation of $1900 \mathrm{~m}$ asl, and the average elevation is $1100 \mathrm{~m}$. As is evident from these dimensions and elevations, the drainage basin comprises an area with steep slopes, reaching up to $55 \%$ at higher elevations and $30 \%$ over much of its area.

The geological location of the drainage basin plays an important role on the silting dynamics of the reservoir, as it

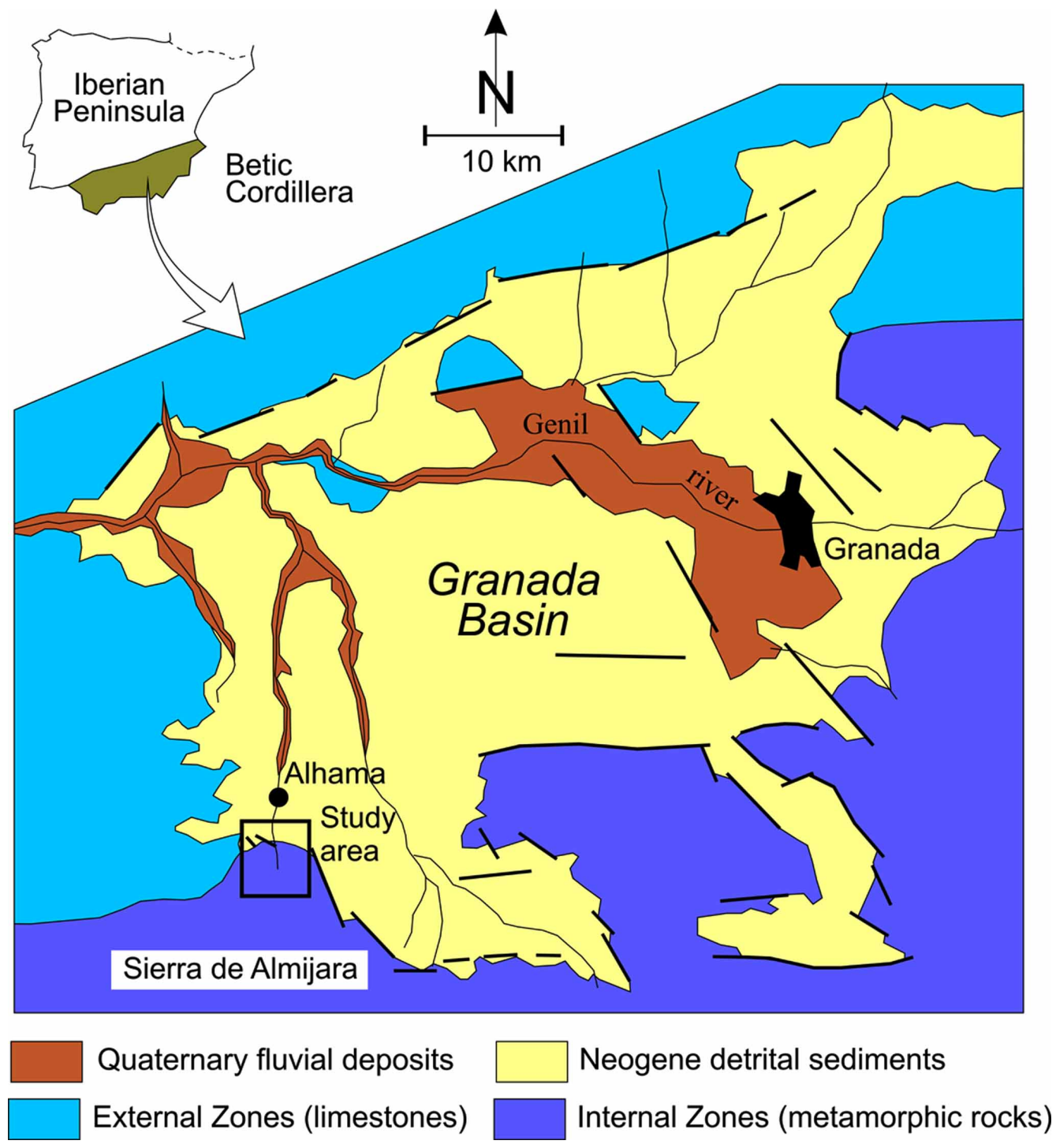

Fig. (1). Location of the Granada Basin in the central Betic Cordillera and the study area in the SW corner of the Granada Basin, to the north of the Sierra de Almijara. The grey area on the map of the Iberian Peninsula outlines the area occupied by the Betic Cordillera. 
lies precisely on the contact between two geological domains with extremely different lithological characteristics: the Alpujárride Complex and the Granada sedimentary basin (Fig. 4). The Alpujárride Complex forms part of the Internal Zone of the Betic Cordillera [17] and in this sector consists of resistant metamorphic rocks (primarily marble and some schist) of Palaeozoic and Triassic age that cover $80 \%$ of the catchment area. The remaining $20 \%$ of the area is Neogene infill from the Granada Basin [16, 18, 19] comprising mainly poorly cemented silts, marls, and sandstones in the northernmost section (also the closest to the reservoir). These two realms will be referred to as the crystalline and detrital source areas, respectively (Fig. 4). Moreover, the agricultural activity is mainly concentrated in the northernmost part of the basin since the detrital source area is easier to till and farther from the high reliefs (and therefore has a more benign climate). Uses include unirrigated crops, fruit orchards, and grazing pastures. In contrast, the crystalline source area is mainly covered by low- and high-mountain vegetation.

This way, due to this important lithological contrast inside the catchment the surface geology and the different uses to which the soil is put (heavily affected by the geology, as mentioned above) largely determine the functioning of the sedimentary systems that contribute to the reservoir siltation. Thus, although the Specific Sediment Yield (SSY) for the southern sector of the Guadalquivir Basin averages $280 \mathrm{t} \mathrm{km}^{-2}$ $\mathrm{yr}^{-1}$ [20], our catchment area (located in the same sector) averages a spectacular $2400 \mathrm{t} \mathrm{km}^{-2} \mathrm{yr}^{-1}$ in the sub-basins in the detrital source area, which is very close to the highest SSY values recorded in Spain (2703 t km-2 $\left.\mathrm{yr}^{-1}[20,21]\right)$. Such huge differences in the SSY from one part of the catchment area to another lead inevitably to the conclusion that there must be tremendous variations in the sedimentary activity and the consequent relative contribution to the siltation of the reservoir in the sedimentary systems based on whether they have a crystalline or a detrital source area (Fig. 5).

\section{METHODS}

\section{Geomorphology and Sedimentology}

This study is based on field data and subsoil data. The first step comprised the identification of sedimentary environments through surface geology recognition and cartography from aerial photographs. Using the most complete series of aerial photographs available, we mapped the same environments currently recognized on seven historical photographs (from 1974, 1977, 1984, 1986, 1992, 1994, and 1995; only the 1995 representative map is reproduced here, Fig. 6) to obtain an exhaustive record of the evolution of the different environments.
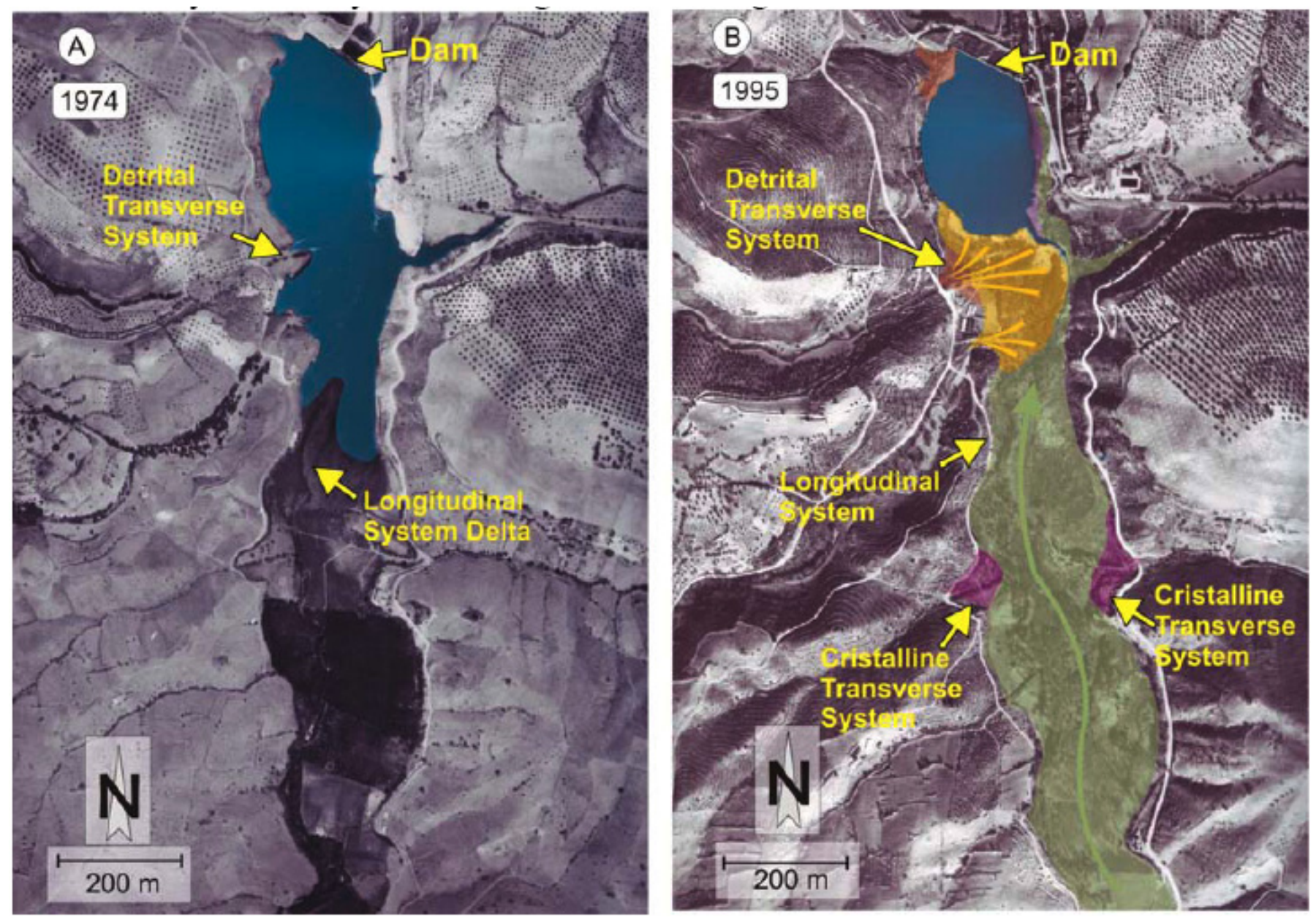

Fig. (2). Evolution of the surface covered by water in the reservoir over a period of 20 years and main sedimentary systems involved in the siltation (see text for explanation). 


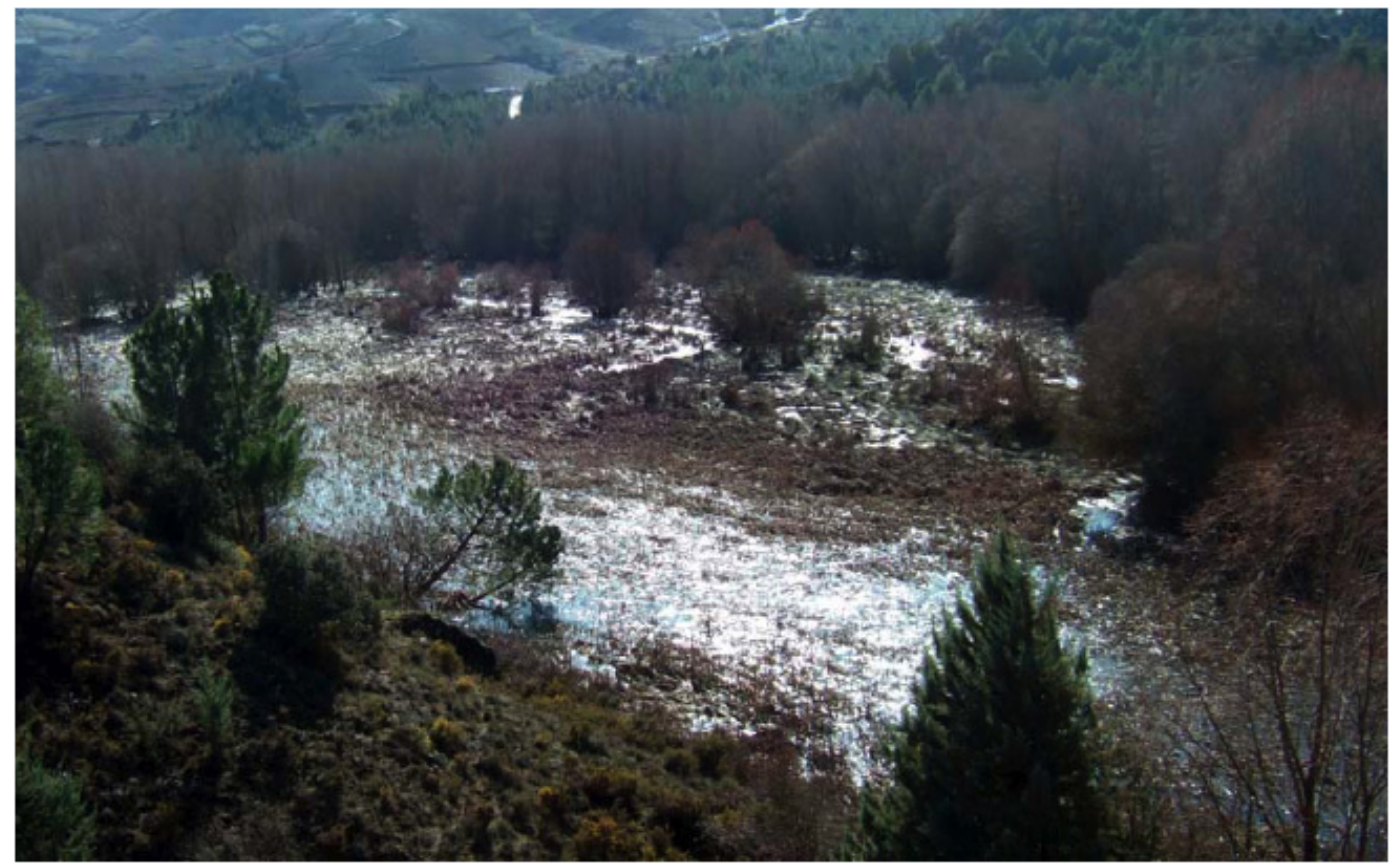

Fig. (3). Image taken in January of 2010, showing the delta plain flooded. The progradation of this delta plain over the delta front has produced a toplap relation visible in the GPR profiles (Fig. 15).

In addition, a total of six shallow trenches were dug with a backhoe at a number of points to categorize the sediments. Due to a high water table, relatively shallow rectangular trenches were dug, from 1-1.5 m wide, 3-5 m long, and an average depth of $2 \mathrm{~m}$ (Fig. 7), although flooded trenches limited observations to the upper section. The data from the trenches were used to draw up a lithofacies diagram containing a total of 13 types corresponding to very specific sedimentary environments and processes (Table 1).

Moreover, Ground Penetrating Radar (GPR) was used to identify six macro- and mesoscale radar facies characteristic of specific sedimentary processes. Contrasting the GPR data with the map series covering 20 years has revealed the stratal stacking patterns and the role of each of the systems involved in the siltation of the reservoir. The combined use of GPR data and shallow-trench observations is an extremely useful methodology for the characterisation of sedimentary processes (e.g. [22, 23]).

\section{GPR Methodology}

GPR methods utilize a pulse of high-frequency electromagnetic energy to detect changes in the dielectric properties of materials [24]. Thus, the reflections obtained correspond to interface surfaces between materials of different properties due to variations in lithology, pore fluid and/or porosity of the sediment [25]. In this example GPR surveys were conducted using a Mala Geosciencies, RAMAC GPR radar with $100 \mathrm{MHz}$ antenna.

We have designed a lattice of GPR lines comprising a total of nine profiles distributed parallel and transverse to the main direction of progradation of the three main delta systems in the basin (significance explained below). The profiles have been labelled with one or two uppercase letters to indicate their correspondence with the longitudinal delta
(L), the transverse delta of the detrital source area (TD), or the transverse delta of the crystalline source area (TC). A lowercase letter indicates whether they are parallel (p) or transverse ( $t$ ) to the direction of flow. Numbers simply indicate the proximal-to-distal order within each delta system. Thus, profile TD2p, for instance, corresponds to the transverse delta of the detrital source area, which runs parallel to the average direction of flow in that delta; it is more distal than TD1p and approximately perpendicular to TD3t and TD4t, which run perpendicular to the flow (Fig. 8).

According to the protocol followed in previous examples $[26,27]$, processing of the GPR data was limited to application of automatic gain control (AGC), band-pass filtering, depth conversion and elevation statics, with the $0.06 \mathrm{~m} / \mathrm{ns}$ signal propagation constant velocity, typical for fresh-water saturated sand [25].

\section{CHARACTERISTICS AND EVOLUTION OF THE ALLUVIAL SYSTEMS}

The study derived from the field geology and aerial photographs (1974-1995) reveal three main groups of sedimentary systems forming part of the sediment feeder system to the lacustrine basin: the longitudinal feeder system (LS), the detrital source area transverse system (DTS), and the crystalline source area system (CTS).

The longitudinal system (LS) consists of the deposits of the main river in the basin - the Alhama. Within the system are two sedimentary environments with quite distinct traits fluvial and deltaic. The fluvial part of the system lies in the proximalmost area and comprises a braided river, although upriver it has reaches of quite high sinuosity due to the structure of the bedrock. Typically, it shows no lateral accretion on the bends, but does have longitudinal and transverse braid bars [28-31] (Fig. 9). This coarse- 


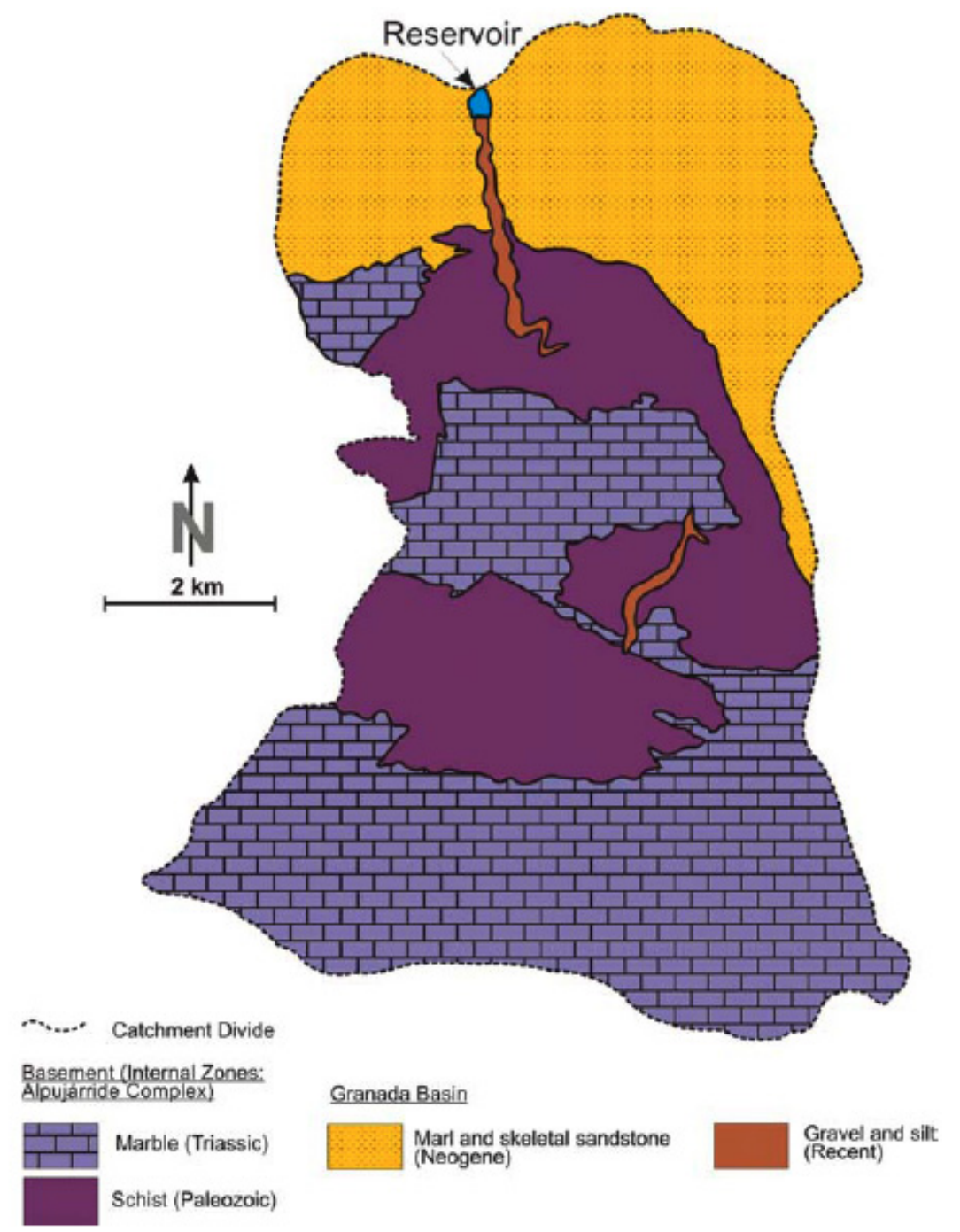

Fig. (4). Geological context of the reservoir and its catchnment, which is sealing the contact between two geological ensembles with very different resistances to erosion.

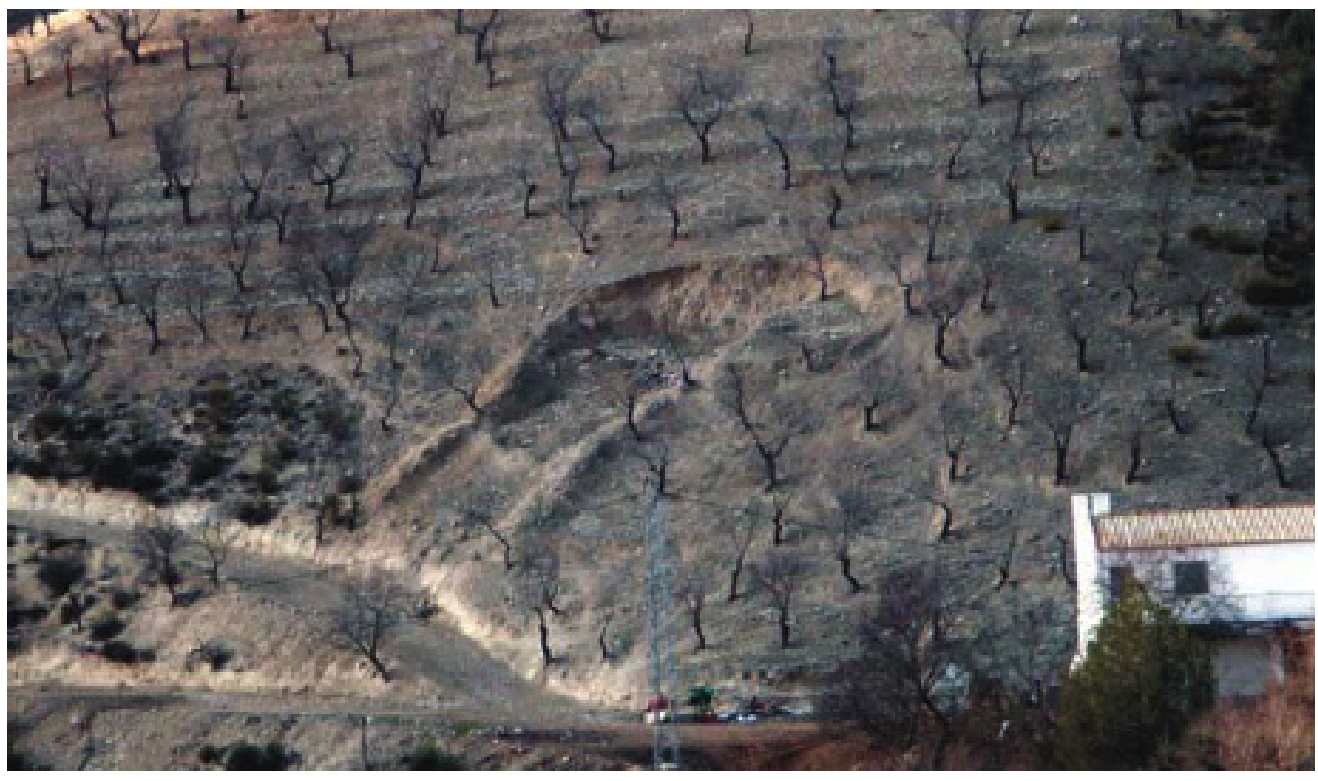

Fig. (5). Small landslide caused by road construction in the detrital source area. Intense human activity in the catchment area covered by the Granada Basin detrital sediments are largely responsible for the huge volume of sediment supply in the transverse detrital system. 


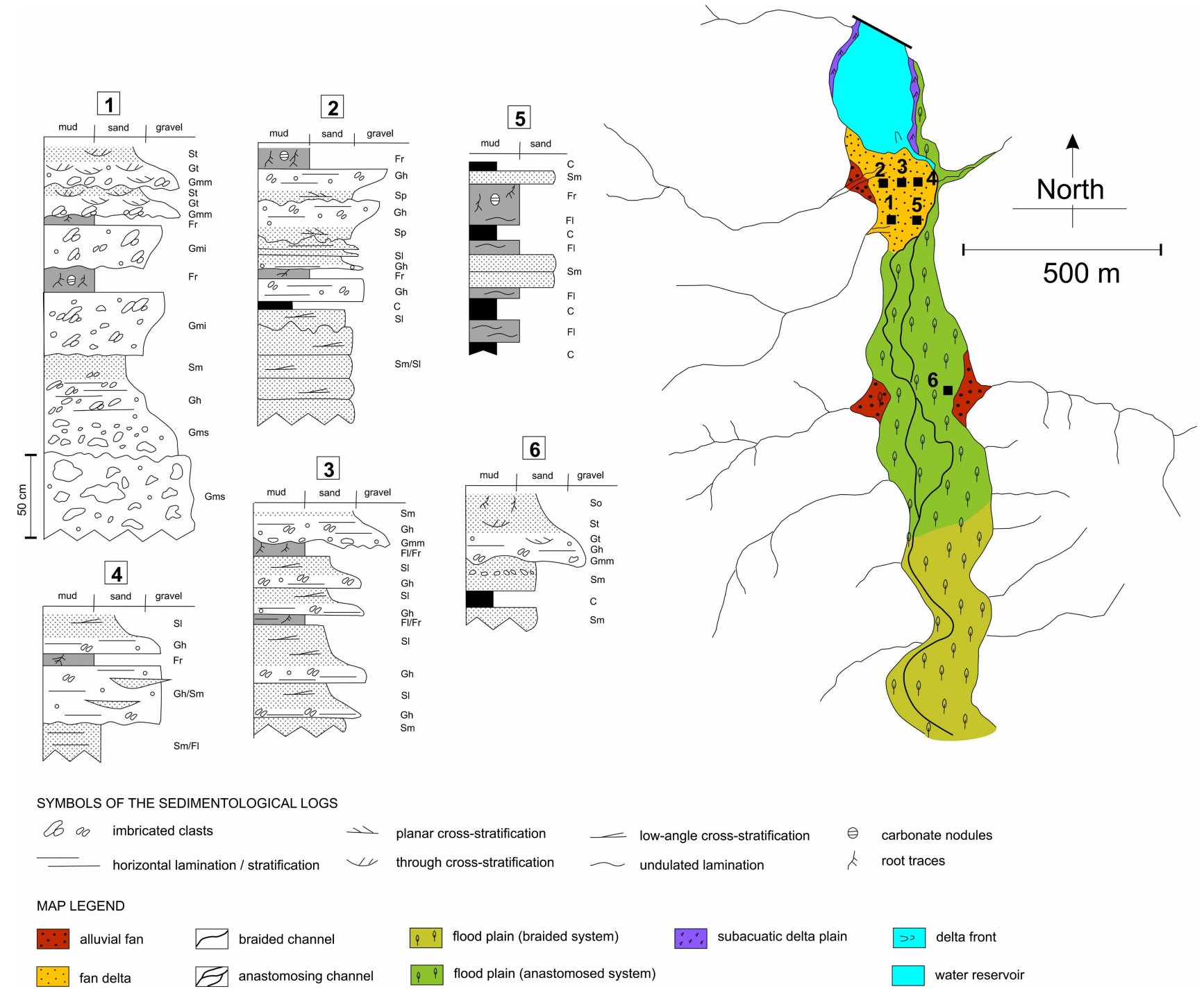

Fig. (6). Distribution map of environments and sedimentological logs of the shallow trenches (map elaborated on the aerial photograph of 1995).

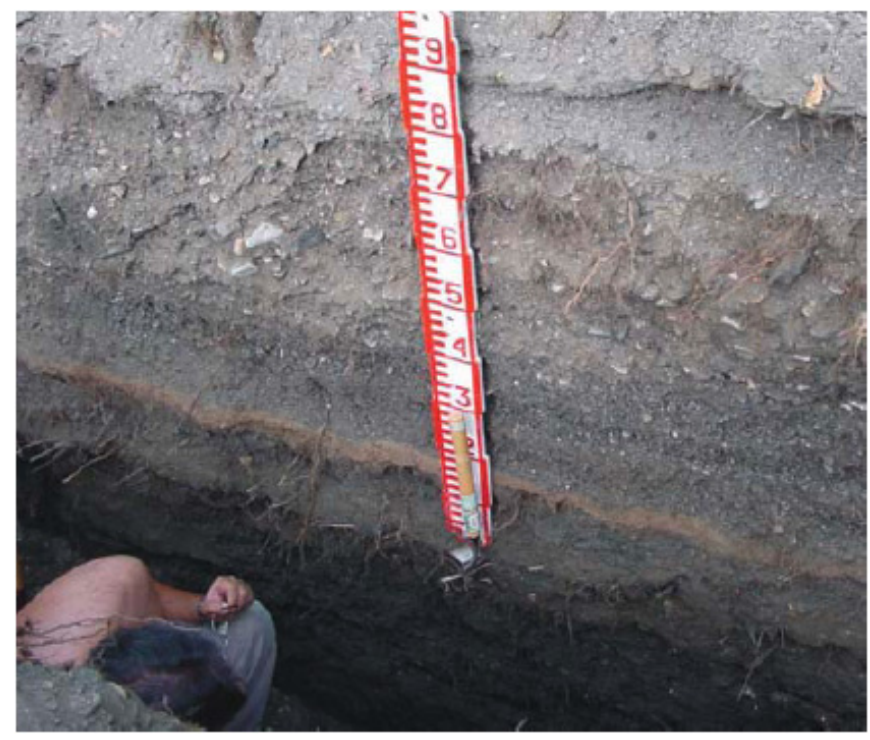

Fig. (7). Photograph of a shallow trench ( $\log 2$ of Fig. 6) showing coarse-grained channel deposits lying over sheet flood and overbank sediments (see Fig. 6 for location). 


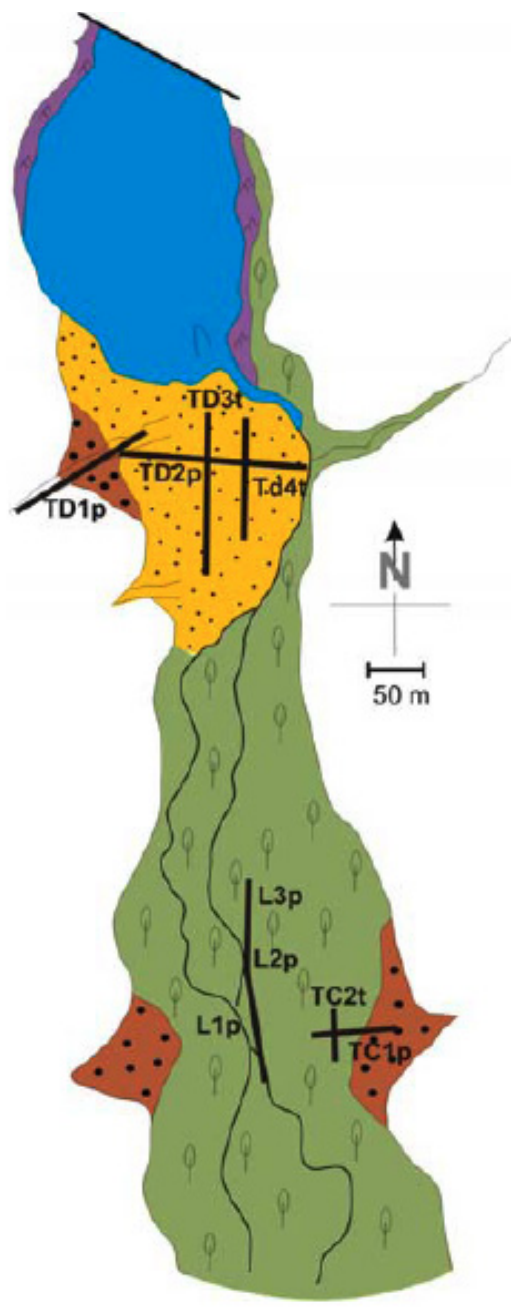

Fig. (8). Schematic localization of the GPR lines and relative positions of the distinct GPR lines showing the above figures in detail.

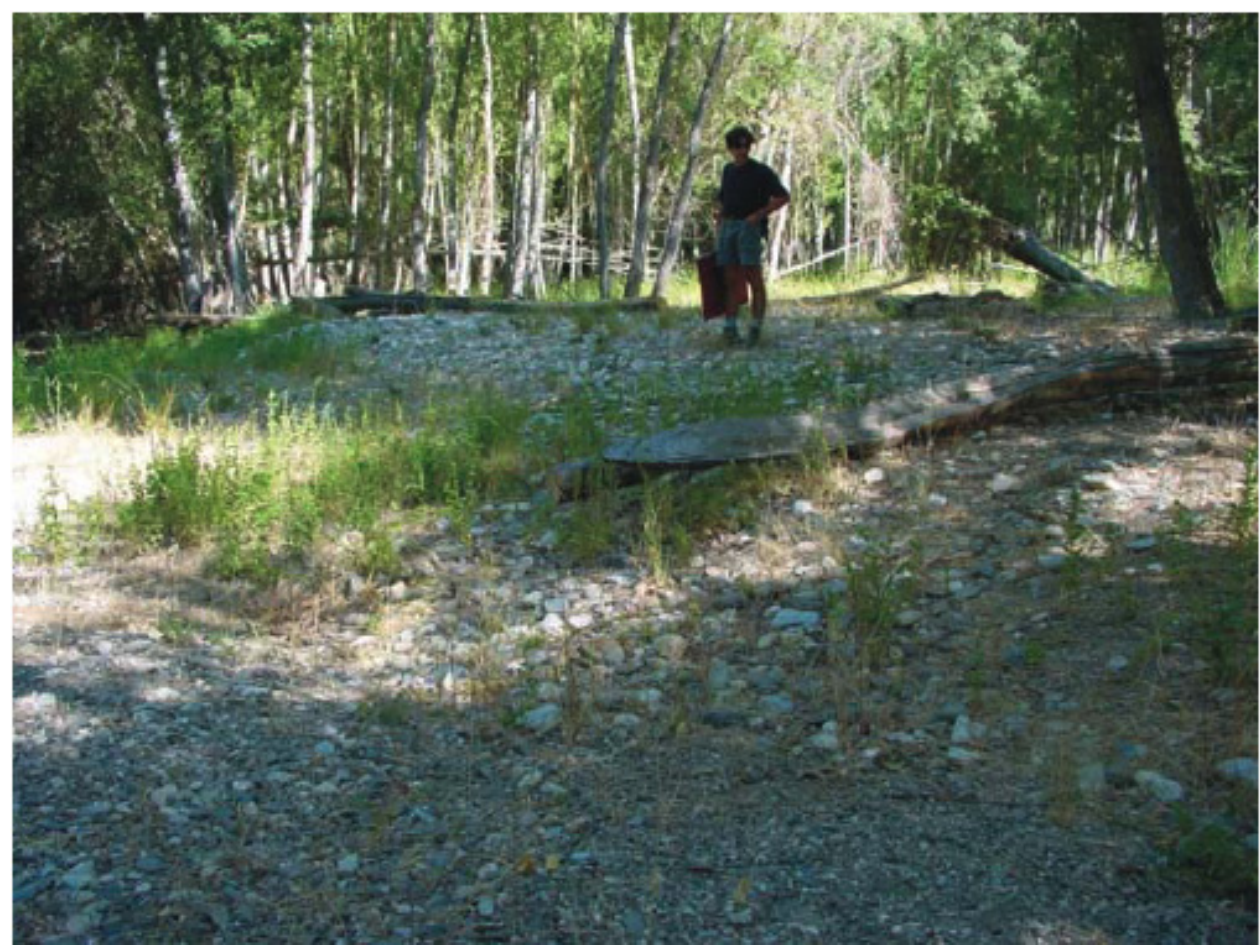

Fig. (9). Coarse-grained braid bars in the longitudinal system upstream of the delta. 


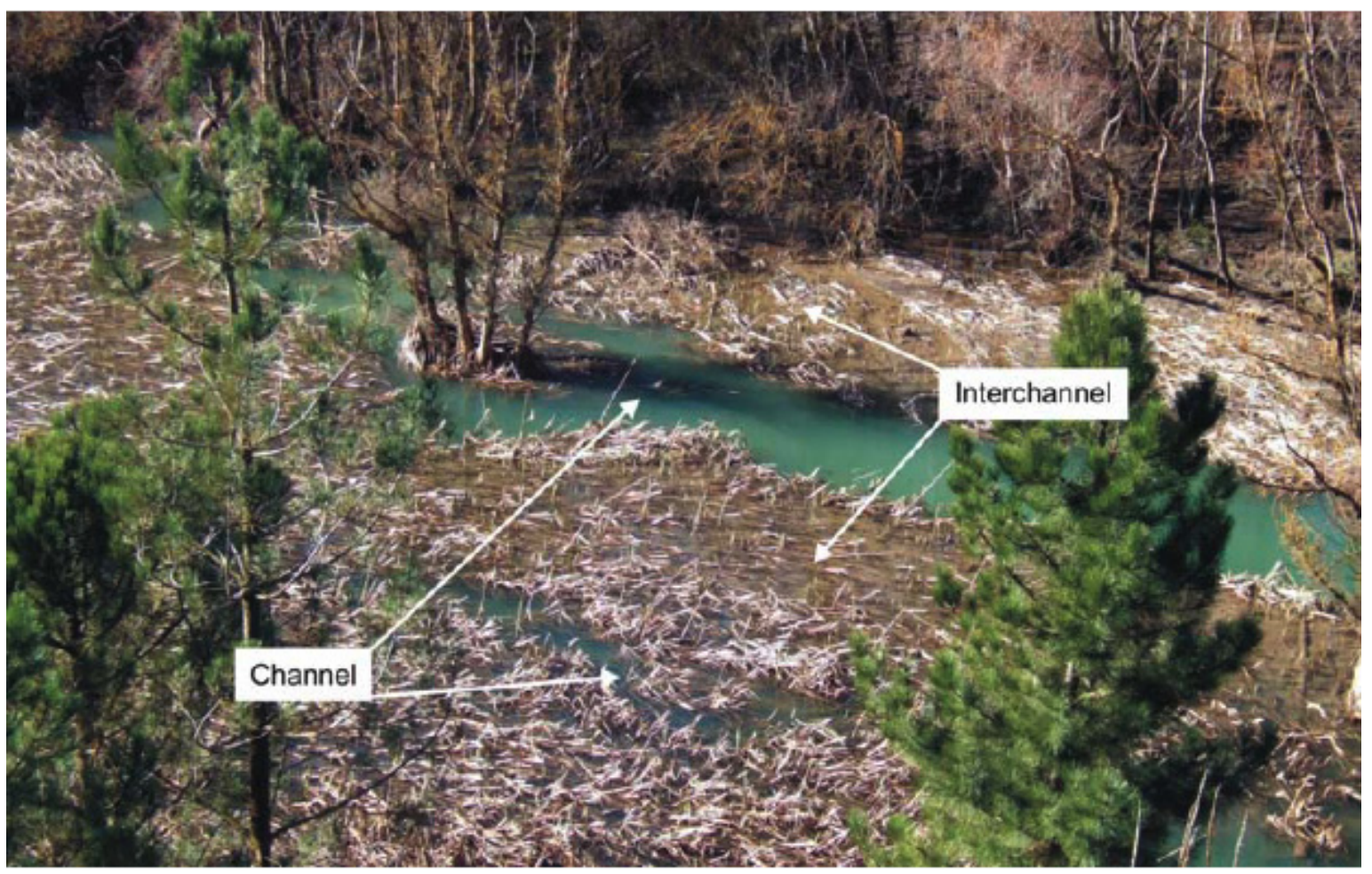

Fig. (10). Close-up of the delta plain in January of 2010. Although almost all of the plain is flooded, the channel and interchannel areas can be made out.

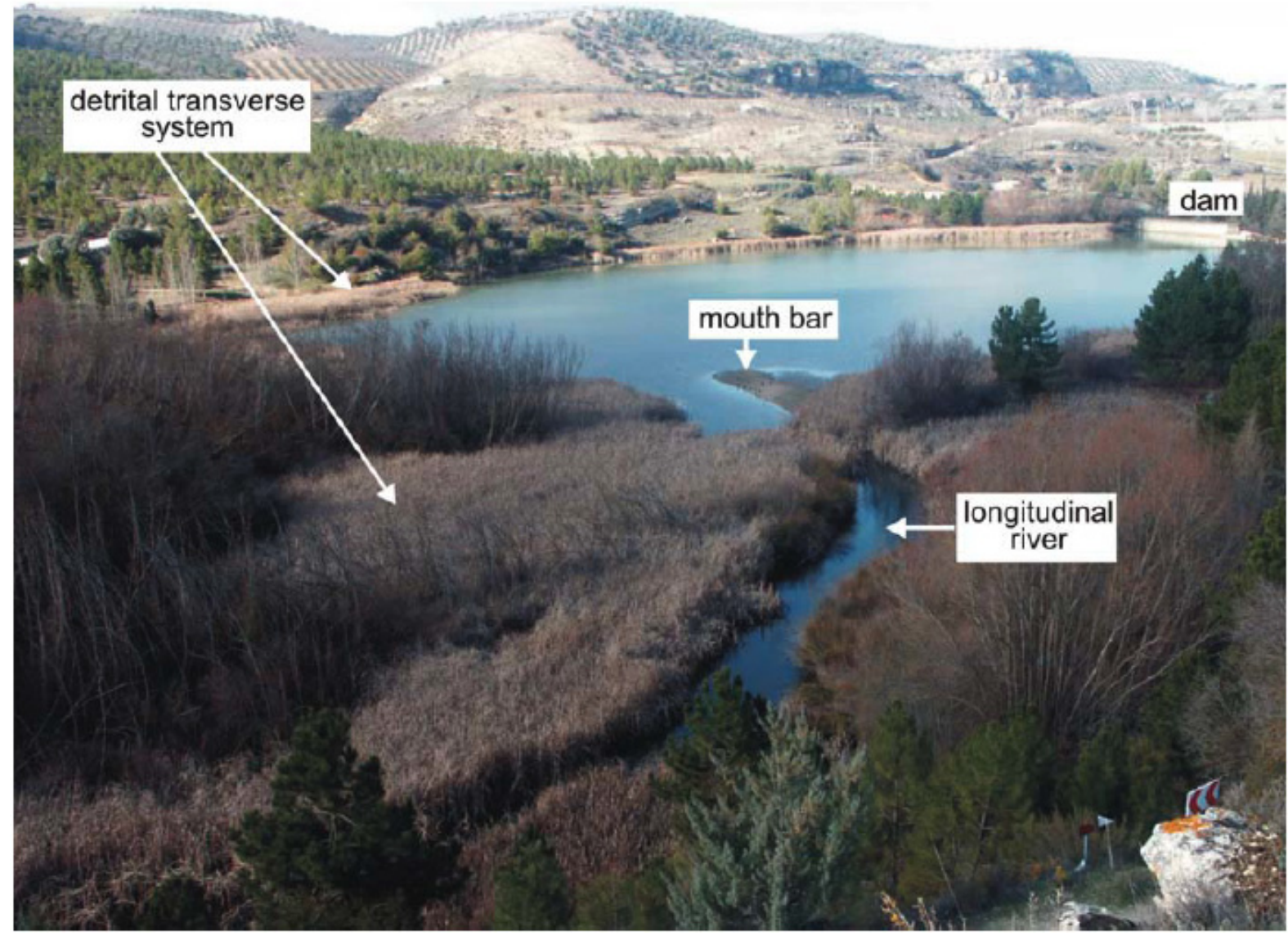

Fig. (11). Photograph displaying the shift of the longitudinal river to the eastern margin of the valley (righthand side of photo) due to the progradation of the transverse fan delta of the detrital source area. A mouth bar can also be seen. 
grained fluvial system is distally connected to the delta environment, on the delta plain of which (after 1984) a network of anastomosed channels arose, characterized by relatively stable channels and thickly overgrown interchannel wetlands (Figs. 3, 10). The delta plain, delta front, and prodelta can be clearly recognized in the longitudinal delta. The delta plain consists of a main channel and a relatively well-developed flood plain with occasional traits that are more typical of an interdistributary bay (Fig. 10). The delta plain, as described in more detail below, underwent numerous changes in its development and facies. The delta front is made of sand-sized sediment and is typified by considerable mobility as regards the progradation of the longitudinal system. Finally, the prodelta is nourished by finer fractions (silt and clay) forming subaqueous mouth bars (Fig. 11). According to previous papers [32-35] the delta can be classified as a shoal due to the gradual slope of the delta front.

Two creeks converge on the $\mathrm{W}$ side of the valley, at a point originally some $400 \mathrm{~m}$ upstream from the dam to develop the detrital source area transverse system (DTS); they are part of a system with a source area located in the easily eroded infill of the Granada Basin that has played a significant role in the reservoir siltation. The site where these two streams enter the lake has seen the development of an alluvial fan-fan delta complex that has grown considerably in the last 30 years (Figs. 2, 11).

Approximately $1 \mathrm{~km}$ upriver, another two alluvial fan-fan delta complexes have been developed on both margins of the river at the point where the slope levels out when the tributaries join the main river (Fig. 6). The source area of these transverse systems is the metamorphic rocks of the Alpujárride Complex, which (as mentioned above) are much more resistant than the Neogene rocks in the sub-basins farther north. The fans of this crystalline source area transverse system (CTS) are therefore much smaller and less active than their detrital-source-area equivalents (Figs. 6, 12).

\section{GPR FACIES AND FACIES ARCHITECTURE: ENVIRONMENTAL INTERPRETATION}

Ground penetrating radar was used to map the subsurface structure and facies of the deltas in the reservoir. Ten profiles of several tens of metres were measured. The full lengths of all the GPR profiles were analysed and interpreted, but only selected profiles are presented in this paper: four profiles at the western transverse fan delta of the detrital source area (profiles TD1p, TD2p, TD3t, and TD4t), a composite profile at the longitudinal delta (profiles L1p, $\mathrm{L} 2 \mathrm{p}$, and L3p), and two profiles at the eastern transverse fan delta of the crystalline catchment (profiles TC1p and TC2t) (Fig. 8).

The radar data are interpreted following the seismic stratigraphic approach [27, 36, 37]. Interpretation of the georadar facies with respect to sedimentary processes and architectural elements has been based on, apart from the afore-mentioned works, the contributions of $[23,25,26,38$, 39].

Six macro- and meso-scale radar facies organized into architectural elements were identified on delta GPR profiles (Figs. 13-16). The various radar facies represent bedforms (e.g., lateral or mouth bars) and macroforms (delta clinoforms, secondary channels) of the deltas. They are described in terms of reflection continuity, shape, amplitude, internal reflection configuration, and external form.

\section{Concave-Up Reflections (CU)}

This radar facies is characterized by a trough-shaped reflection pattern. Hummocky/wavy and sigmoidal reflections overlie the curved reflections. These reflections are best observed near the surface in the GPR profiles oriented perpendicular to flow (TC2t) and parallel to flow (TD1p, L1p, L2p, and L3p). The lateral extent is between 5 to $15 \mathrm{~m}$ and depth ranges from 0.5 to $2.5 \mathrm{~m}$.

Interpretation: channel fill. These radar facies represent erosion surfaces, a classic bowl shape that defines secondary

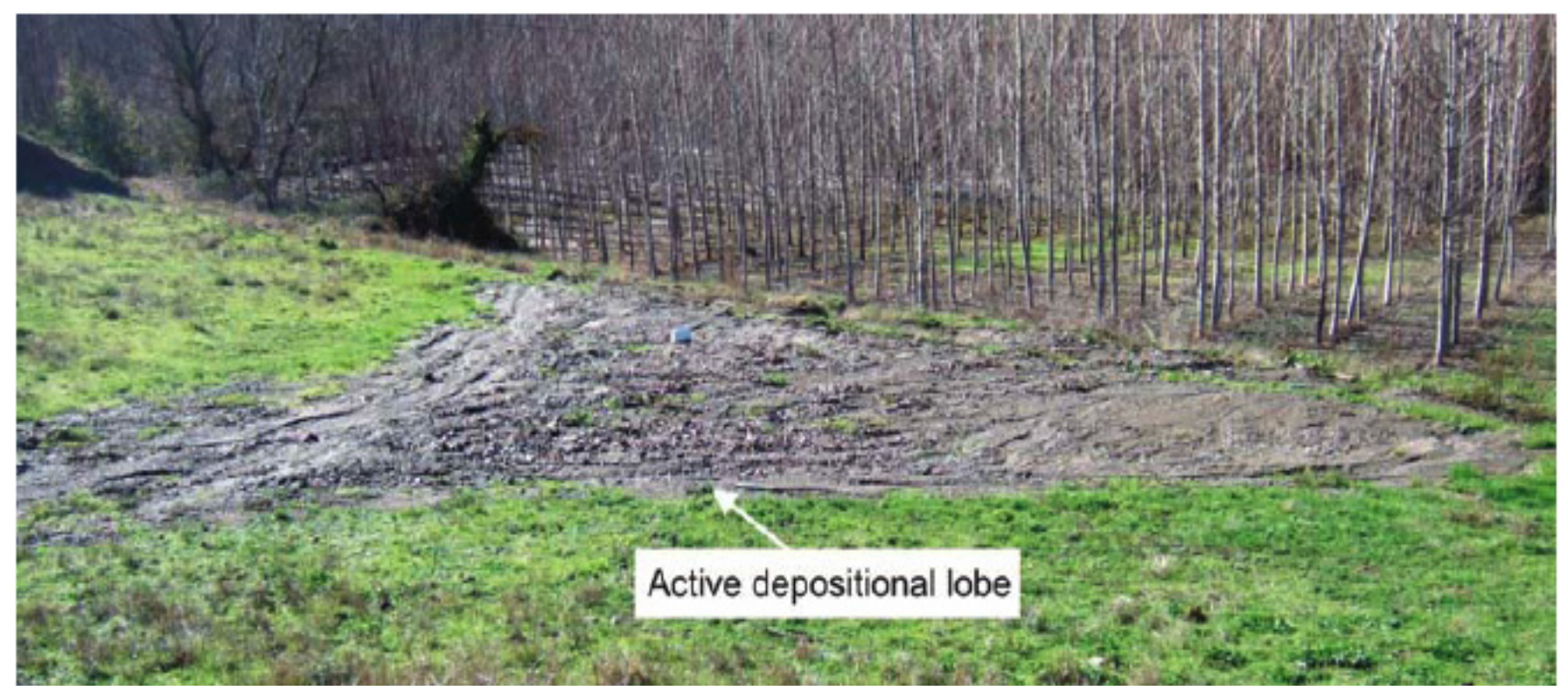

Fig. (12). Photograph of a small active depositional lobe developed on the CTS fan as a result of the activity in the winter of $2009-2010$. 


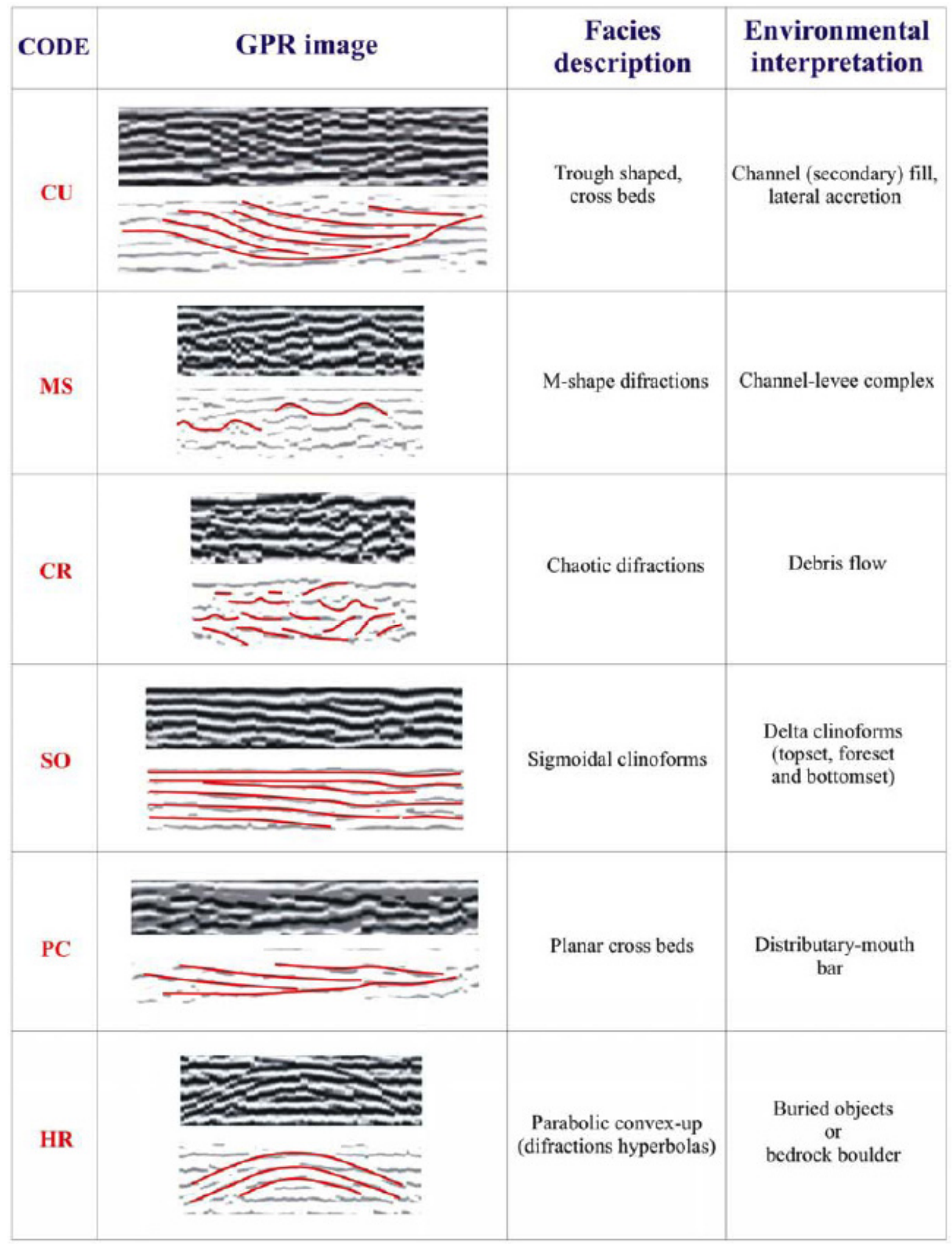

Fig. (13). Environmental interpretation of the most characteristic GPR facies associations (modified from [16]).

channels within the delta feeder system (TD1p) and channels within the delta plain subenvironments (Fig. 17). The depth of the primary channel within the delta feeder system is 2.5 $\mathrm{m}$ (profile TD2p) and secondary channels within the feeder system and delta plain range from 0.5 to $1.5 \mathrm{~m}$, below bankfull conditions (profiles TD2p, L1p and TC2t). Sigmoidal reflections correspond to a variety of internal structures such as epsilon cross-beds and/or longitudinal bar foresets, which in turn are evidence of channel and/or bar migration and point-bar deposition (profile TD1p). The vertical thickness of the cross-channel accretion assemblage is consistent with channel depths. 

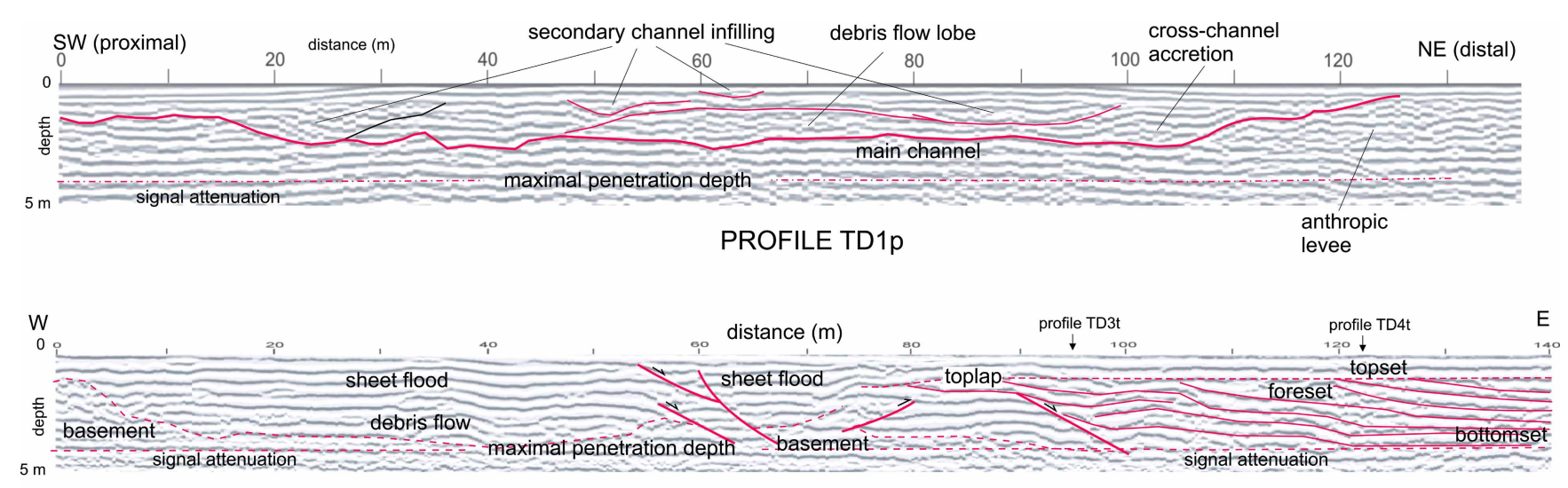

PROFILE TD2p

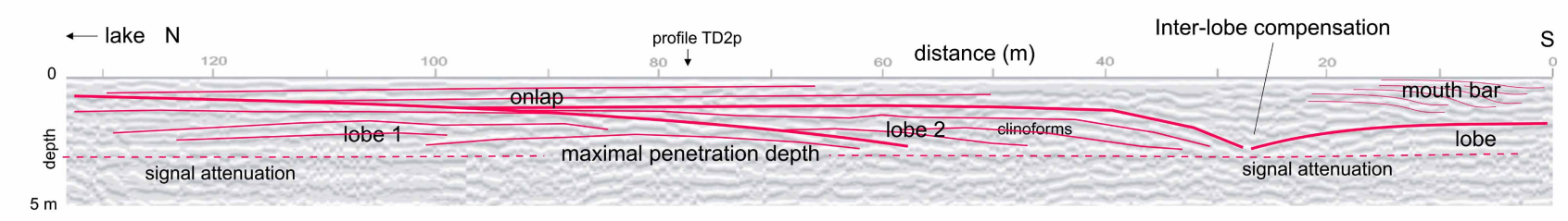

PROFILE TD3t

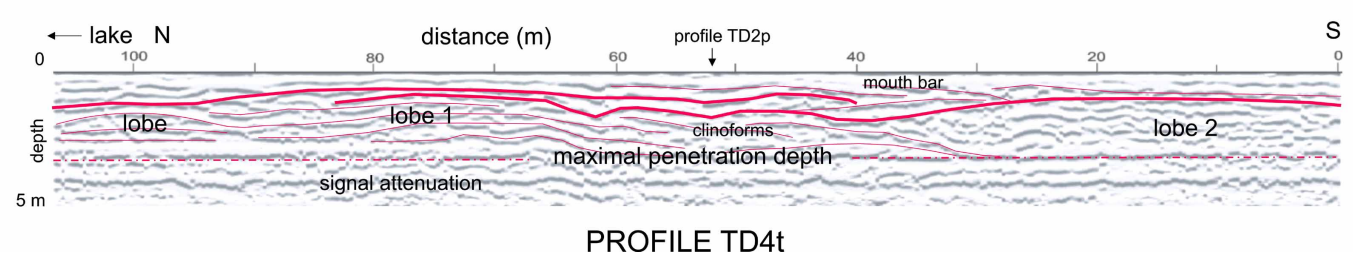

Fig. (14). Interpreted GPR profiles in the DTS (see Fig. 8) for location.

\section{Meso-Scale m-Shaped Reflections (MS)}

The meso-scale m-shaped reflections (MS) have a flatupward convex profile characterised by a central channel (profiles TD1p, L2p and TC2t). On each side of this central zone, there are depositional wedges with subparallel reflectors that thin outwards from the central channel.

Interpretation: channel-levee complex. These radar facies represent natural levee deposits bordering a deltaic distributary-channel infill.

\section{Macro-Scale Sigmoidal and Oblique Reflections (SO)}

This radar facies represents sigmoidal and oblique clinoforms which consist of horizontal reflections in the upper part, reflections that are gently inclined downstream in the middle part, and horizontal reflections once again in the lower part of the clinoform.

Interpretation: delta clinoform GPR facies. The GPR profile clearly reveals that the topset of the oblique clinoforms has a base that is erosional and unconformable to the underlying foreset (TD2p, TC1p). The facies of delta plain beds distally change to delta front beds in sigmoidal clinoforms (profile L1p).

\section{Horizontally Continuous, Layered Parallel Reflection Pattern}

This reflection pattern is characterised by subhorizontal, continuous (reflections can be followed for several tens of metres) to wavy reflectors (profile TD2p). Subhorizontal reflectors are thought to reflect bedload sheets. They are

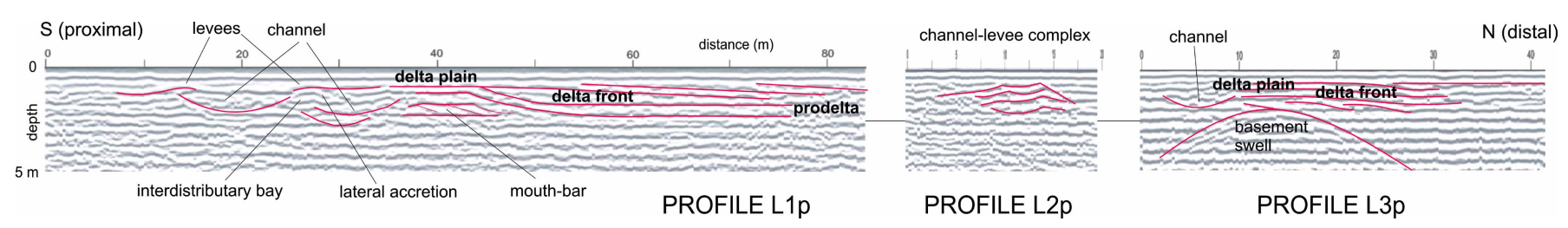

Fig. (15). Interpreted GPR profiles in the LS (longitudinal axial system) (see Fig. 8 for location). 

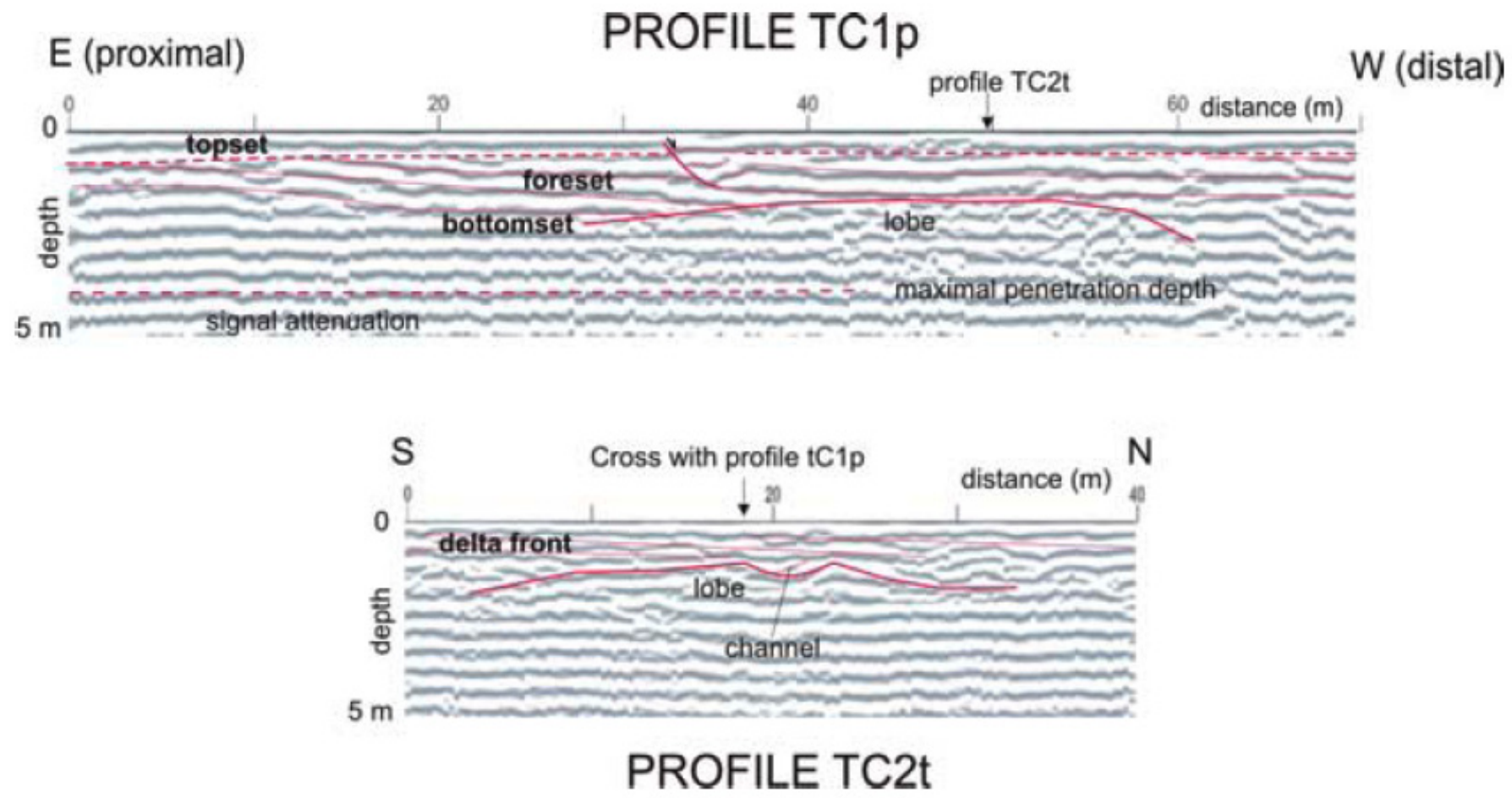

Fig. (16). Interpreted GPR profiles in the CTS (see Fig. 8 for location).

locally truncated by convex-up erosive reflectors (channel GPR facies). Generally, this pattern is found at higher stratigraphic positions in the profiles.
Interpretation: This facies is interpreted as stratified sheetflood gravel and sand and matrix-rich debris-flow in delta plain subenvironments.

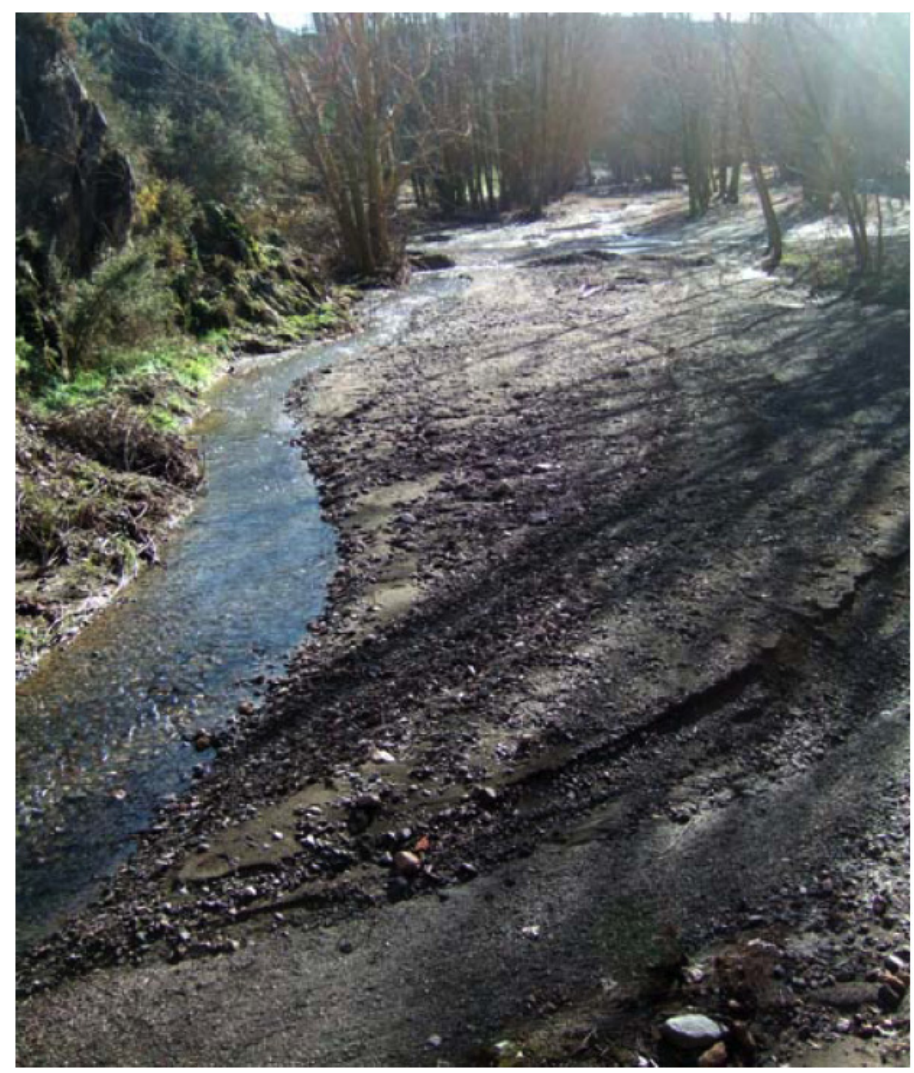

Fig. (17). Bar development and lateral channel shift equivalent to the CU georadar facies. The photograph is above the site of the georadar profile TD1p (Fig. 14). 


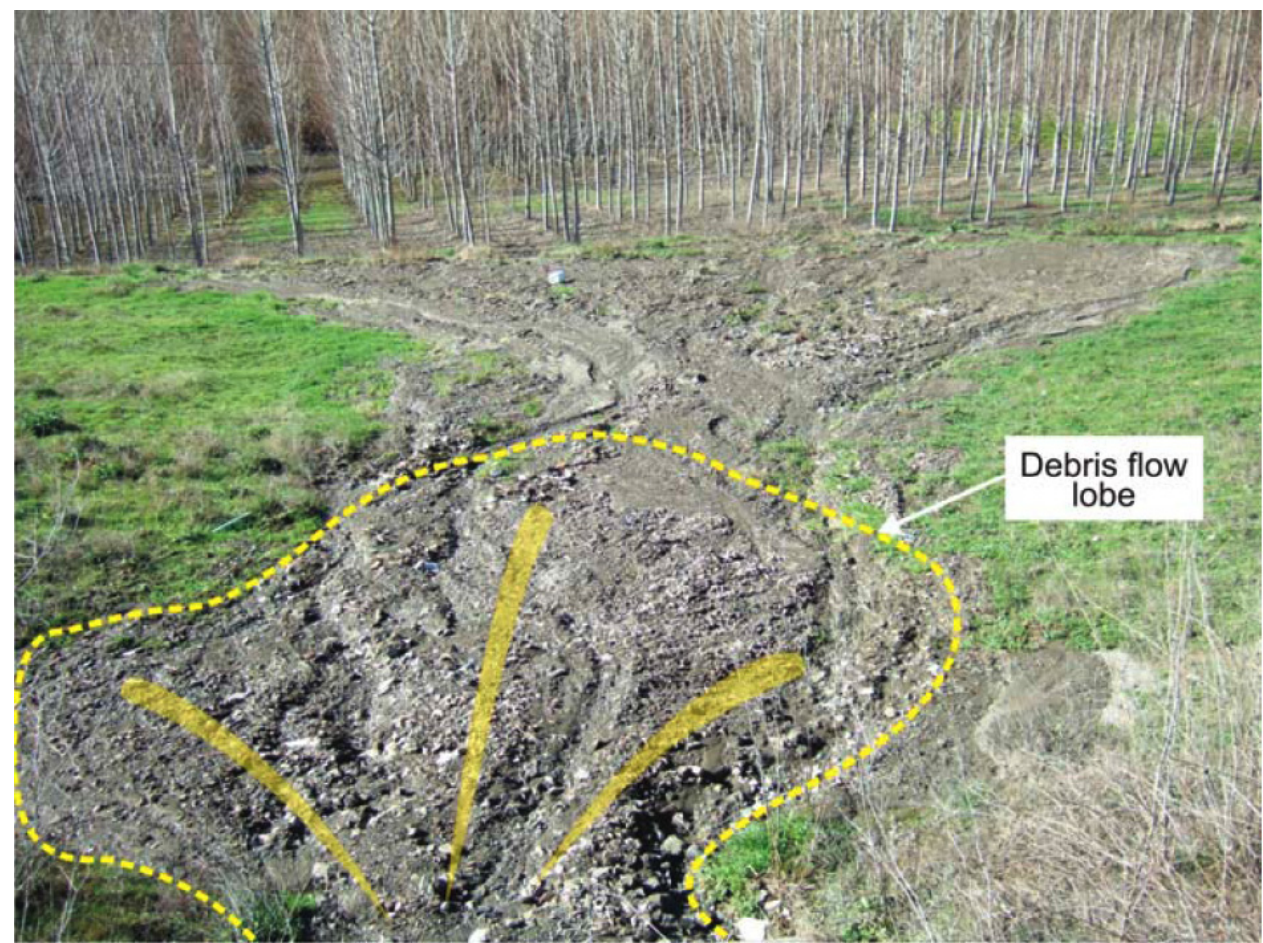

Fig. (18). Lobe of debris flow deposits later dissected by small channels, formed in a transverse fan in the winter of 2009-2010. Equivalent to the CR georadar facies. In a more distal section (background of photo), note the deposits of the flow expansion of the channels, cutting through the debris flow lobe.

\section{Reflections Gently Inclined Downstream}

Low-angle clinoform reflections $\left(3-5^{\circ}\right)$ appear typically truncated and bounded by overlaid subhorizontal continuous reflections (delta plain GPR facies). Low-angle clinoform reflections are relatively straight and roughly parallel to each other. The reflectors are steeper in the upper part of the delta front and may flatten to nearly horizontal in the lower part transitional to the prodelta. The low-angle clinoforms are best developed in flow-parallel GPR profiles and dip in the direction of flow (profiles TD2p, L1p, L3p, and TC1p).

Interpretation: These reflections were identified as front delta beds.

\section{Horizontally Continuous, Layered Parallel Reflection Pattern}

This reflection pattern is characterized by parallel, subhorizontal continuous to wavy reflectors (profiles TD2p and L1p). Discontinuous, chaotic reflections can be identified at the foot of the delta front truncating the typical continuous horizontal reflections.

Interpretation: This reflection pattern is interpreted as prodelta deposits. Chaotic reflections are interpreted as debris flow lobes resedimented from the proximal foreset following [32-35].

\section{Planar Cross Reflections (PC)}

Parallel/planar and low-angle clinoform reflections 40 $\mathrm{cm}$ high overlie flat reflections at the uppermost part of the profiles (TD3t, TD4t).

Interpretation: distributary-mouth bars. This GPR facies is interpreted as representing cross-bed sets associated with progradation (and aggradation) of distributary-mouth bars (Fig. 11).

\section{Chaotic Reflection Pattern (CR)}

This facies is characterised by a chaotic, discontinuous (low lateral continuity) and poorly defined reflection pattern. Convex-up reflections overlie the chaotic reflections.

Interpretation: debris flow. The chaotic pattern indicates a lack of internal structure. They are interpreted as debris flow resedimented deposits from the upper part of the clinoforms or primarily deposited in the subaerial parts of the fans [40, 41] (Fig. 18).

\section{Hyperbolic Reflections (HR)}

Sections with hyperbolic facies are characterised by a prominent, irregular single reflection. Their internal pattern is often one of stacked hyperbolas or diffractions in an inverted chevron (profile L3).

Interpretation: buried objects (wood, roots) or bedrock swell. Hyperbolic configurations arise as a result of the response of the divergence of the GPR to an irregular boundary.

\section{GPR PROFILE DESCRIPTION: EVOLUTION OF DEPOSITIONAL ENVIRONMENTS AND GROWTH PATTERNS}

\section{Flow-Parallel GPR Profiles (TD1p, TD2p, L1p, L2p, L3p and TC1p)}

In general, reflections are more continuous on the GPR profiles oriented approximately parallel to flow. Parallel/planar reflections that are subhorizontal and high- 


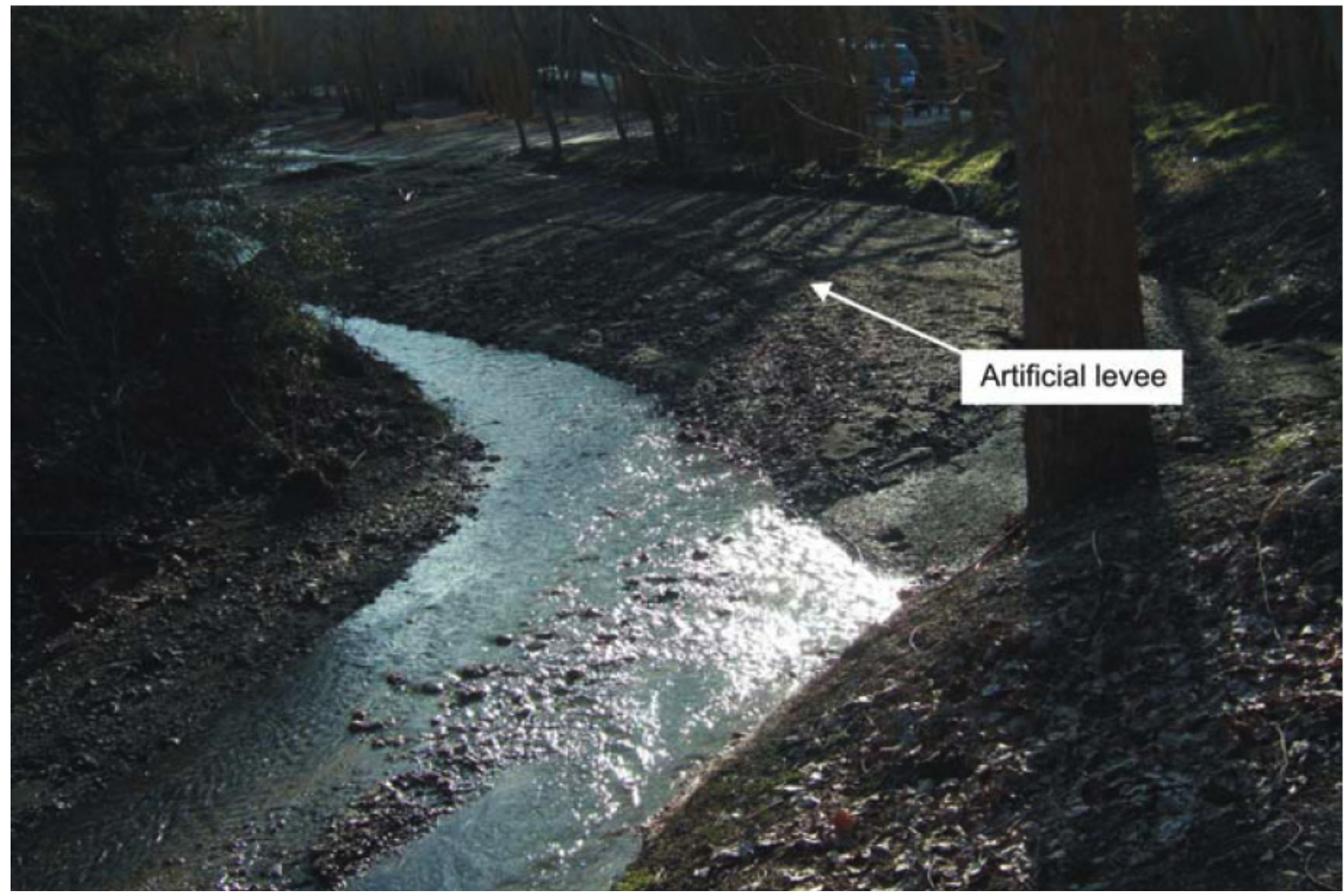

Fig. (19). Channel and artificial levee recognized in the subsoil of profile TD1p (Fig. 14).

angle clinoform reflections that dip downstream are typical of flow-parallel profiles.

\section{Flow-Transverse GPR Profiles (TD3t, TD4t, TC2t)}

GPR profiles that cross the deltas (roughly perpendicular to flow) typically exhibit a complex hierarchy of convex-up reflections (positive relief) at the lower part of the profile and discontinuous concave-up reflections (negative relief) at the upper part that truncate the shorter hummocky/wavy reflections.

In some georadar profiles, several sequence boundaries can be identified (e.g., profile TD1p). One type of boundary is concave-up and can be recognized over distances surpassing $100 \mathrm{~m}$; they are interpreted as the bases of a delta feeder system multi-storied by secondary channels (minor sequence boundary) and a braided bar complex (Figs. 14, 17). Another type of radar sequence boundary exhibits convex-up geometry 1.5-2 m high and tens of metres wide, representing lobes (profiles TD3t, TD4t) (Figs. 12, 14).

\section{Transverse fan Delta of the Detrital Source Area (Profiles TD1p, TD2p, TD3t, TD4t, Fig. 14)}

\section{Profile TD1p}

This profile represents a delta-feeder system multistoried by secondary channels. The main channel is bounded by an artificial levee encouraging cross-channel accretion (Fig 19). Debris flow lobes in the lower part of the main channel and secondary channel infilling in the middle and upper part could be related to an upward decrease in the matrix proportion in the flows, which changes from cohesive or cohesionless debris flows to stream flows. Stacking of the secondary channel could indicate rapid channel avulsion, typical of braided river systems. Accordingly, sigmoidal reflections in channels probably represent lateral or longitudinal braided bars. The thinning-upward secondary channel sequence is interpreted as the upward decrease of flow energy.

\section{Profile TD2p}

Synsedimentary faults cutting the delta deposits are interpreted as a result of a high sedimentation rate. Subhorizontal deposits in the western part of the profile represent debris-flow deposits changing upward to sheetflood deposits (Fig. 18). Delta foresets are identified in the eastern (distal) part, truncated and bounded by overlaid topset beds, which indicate a high rate of sediment supply.

\section{Profiles TD3t, TD4t}

Two or three amalgamated delta lobes separated by unconformities indicate a radial delta growth pattern from the northeast (delta lobe 1) to the southeast (delta lobe 2). Distributary mouth-bars migrating to the southeast in the uppermost part of the profiles confirm the progradation of the youngest delta lobes to the southeast.

\section{Longitudinal Delta (Profiles L1p, L2p, L3p, Fig. 15)}

These profiles show a shoal delta (delta front beds dip less than $5^{\circ}$ ) prograding to the north. The delta is fed from distributary channels bounded by levees indicating fast growth rates for plants, which stabilized the riverbanks and encouraged the development of an anastomosing river plain (two contemporaneous channels laterally bounded by 
interdistributary bay-levee deposits can be distinguished in profile L1p) (Fig. 10). The decreasing-upward dip of the delta-bed (the uppermost reflectors of the profiles show a horizontal and continuous pattern) could be related to a final aggradational stacking pattern.

\section{Transverse Fan Delta of the Crystalline Source Area (Profiles TC1p, TC2t, Fig. 16)}

Due to accessibility problems, only the delta on the E side of valley has been studied in detail (Fig. 11).

These profiles show a delta prograding to the northwest. Topset-foreset truncation surface and synsedimentary faults are interpreted as being a consequence of the high sediment supply. A lobe at the base of the delta front may be resedimented debris-flow deposits from the upper part of the clinoforms or a small submarine fan comprising a channellevee system fed from the delta.

\section{LITHOFACIES DISTRIBUTION AND SEDIMENTARY PROCESSES}

The analysis of trenches dug in the three delta systems (Fig. 6) has identified a total of 13 simple lithofacies characterising the distinct sedimentary environments in these deltas and the sedimentary processes operating in them
(Table 1). Trenches could not be dug in the distalmost sectors of the deltas due to inaccessibility to the heavy machinery.

The most proximal transverse alluvial fan-fan delta complexes are mainly characterized by five gravel lithofacies (Fig. 6, Table 1). These lithofacies comprise the following: 1) matrix-supported boulders carried by debris flows [42] (lithofacies Gms), primarily found in the feeder channel of the transverse fan in the detrital catchment; 2) massive or normal-graded clast-supported granules and cobbles, usually having weak clast imbrication $(\mathrm{Gmm})$, corresponding to lag or braid-bar head deposits in the talweg of the channels [43, 44] (Figs. 9, 17); 3) imbricated graded clast-supported gravels with horizontal or low-angle cross stratification (Gh) corresponding to the initial upper-flow regime phase of sheet flows in the medial to distal parts of the subaerial fans [40, 45] (Fig. 12); 4) channels filled with granules and pebbles transported by the migration of megarripples giving rise to trough-cross bedding (Gt); and 5) levee and crevasse lobe deposits corresponding, according to [43], to the overbank of granules and pebbles (usually imbricated and reverse graded) from the channels onto the flood plains (lithofacies $\mathrm{Gmi}$ ) (Figs. 20, 21).

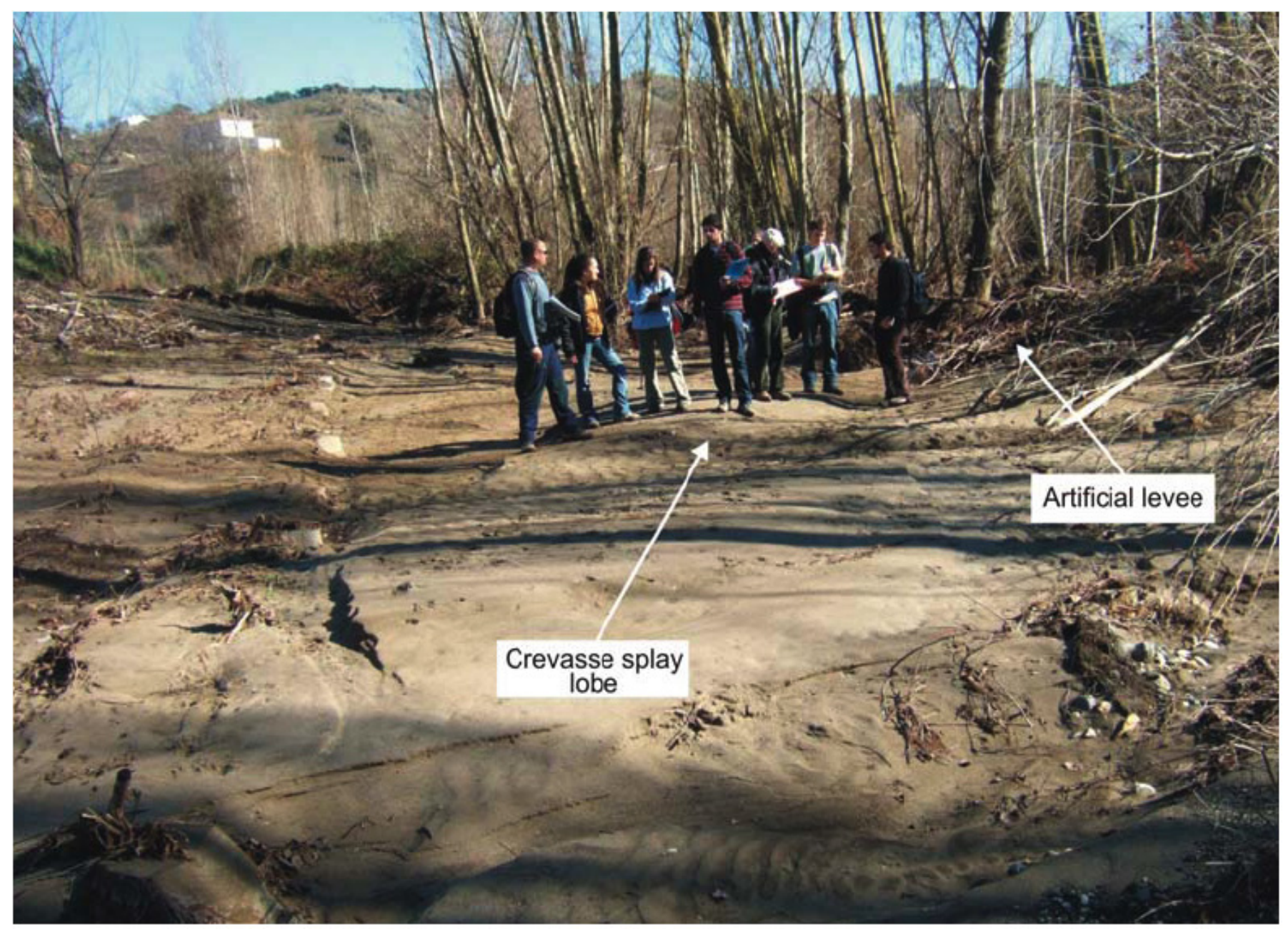

Fig. (20). Crevasse-splay lobe formed by the localized rupture of the artificial levee of the main channel in the floods of the winter of 20092010. 


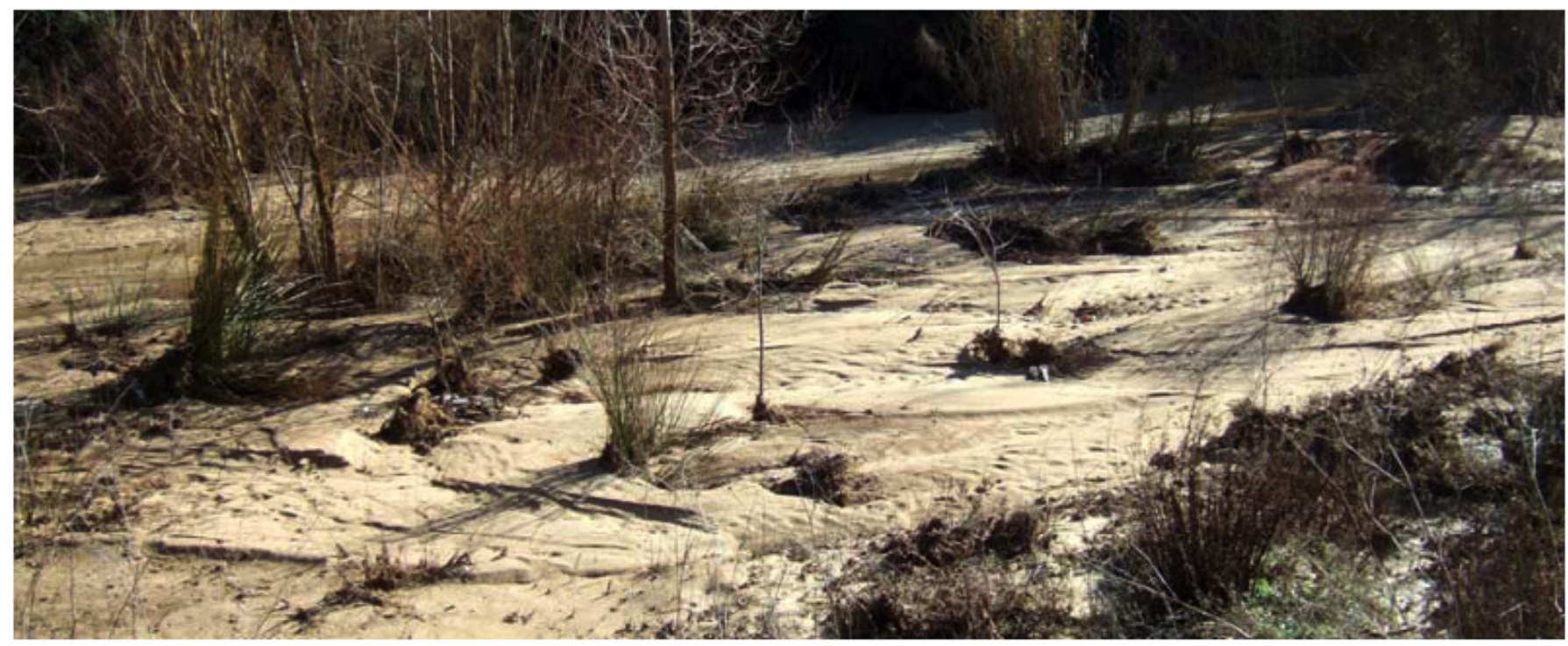

Fig. (21). High-energy sandy deposits in the flood plain due to overbank flows during the floods of the winter of 2009-2010.

The sandy sediment is a medium to fine, normal graded sands or massive sands sometimes forming part of the channel fills and sometimes due to episodes of overbank on flood plains $(\mathrm{Sm})$, appearing as coarse and very coarse planar-bedded sand (Sp) forming braid bar tails [46], as medium-to-coarse trough cross-bedded sand $(\mathrm{St})$ representing minor channel fills or megarripples and dune migration, as massive fine- to medium-grained sand, often showing root bioturbation (So) characterizing vegetated flood and delta plains [32, 47], and very coarse horizontal to upstream gently dipping sand (Sl) representing the decay phase in a sheet flow event $[40,48]$.

Horizontal mud or wavy laminated sediments (Fl) occasionally incorporating isolated small-scale sandy ripples represent mainly low-energy overbank on the flood plain or interdistributary bay deposits in the longitudinal delta. These deposits are at times bioturbated by roots and may also have carbonate nodules (Fr) revealing pedogenesis on the overbank deposits, according to [43, 45, 49].

Finally, the interdistributary bays of the longitudinal delta plain characteristically have facies of massive dark clay with plant remains $(\mathrm{C})$ deposited by the settlement of clay and organic material in still waters.

\section{DISCUSSION: FROM THE GEOMORPHIC FEATURE TO THE BASIN ARCHITECTURE}

There have been three phases in the dynamics of the reservoir siltation: early, intermediate, and final. This division is based on the spatial evolution of the sedimentary environments in the last 30 years, the characteristics and distribution of lithofacies and their associations identified in the trenches and their corresponding geomorphic features, the analysis of georadar facies, and the growth patterns in the three sedimentary systems.

When the dam came online in 1974, the three delta systems developed quickly. The role of the longitudinal delta was particularly significant in filling the reservoir during this early stage, prograding into the lake some $100 \mathrm{~m} \mathrm{yr}^{-1}$. During this stage (1974-1977), the crystalline-source delta complexes expanded only moderately. In contrast, in the same three years, the detrital source area transverse complex surged eastwards some $70 \mathrm{~m}$.

During the eight-year period between 1977 and 1984, the distalmost section of the longitudinal delta extended only $200 \mathrm{~m}$ downstream. In this phase the most significant sediment supply is from the west, with the construction of a huge alluvial fan-fan delta complex in the transverse system of the detrital source area. This complex prograded rapidly eastwards until it reached the opposite side of the valley, thus obstructing the northward development of the longitudinal system (Fig. 11).

Interestingly, in the last 25 years (1984-present) the areal distribution of the sedimentary environments has remained nearly unchanged, although their dynamics and growth patterns have undergone numerous transformations. The transverse fan deltas of the crystalline source area have barely expanded at all, whereas the western delta of the detrital source area has extended slightly southeastwards. The detrital transverse fan delta has obstructed the longitudinal system, preventing the latter from prograding downlake. Nevertheless, this obstruction has substantially affected the ancient longitudinal delta plain, which has become an anastomosed fluvial system. The eastern wall of the valley obstructs the progradation of the transverse system of the detrital source area. The latter, in turn, obstructs the axial delta; thus, in this final phase both systems essentially comprise an aggrading stratal pattern visible in the georadar data. Also, contributing to this aggradational growth pattern is the accommodation space created as a result of the artificial rise in water levels in the lake of some $120 \mathrm{~cm} \mathrm{[41,}$ 50-52]. Remarkably, throughout the 25 years or so of this phase, the lake perimeter has scarcely shrunk. The sediment supply to the lake from the three systems has not been large, mainly comprising the settling-out of fines not trapped in the anastomosed plain (undergoing rapid vertical growth) and sediments deriving from the destruction of the northern margin of the delta of the detrital source area due to geotechnical instability. This delta is also advancing somewhat southeastwards, not towards the lake. The 
Table 1. Characteristics and Interpretation of the Lithofacies Identified (Based on [45])

\begin{tabular}{|c|c|c|c|c|c|c|}
\hline & CÓDE & TEXTURE \& FÁBRIC & $\begin{array}{l}\text { SEDIMENTARY } \\
\text { STRUCTURES }\end{array}$ & $\begin{array}{l}\text { SETS \& BED } \\
\text { THICKNESS }\end{array}$ & $\begin{array}{l}\text { SEDIMENTARY } \\
\text { PROCESS }\end{array}$ & ENVIRONMENT \\
\hline \multirow{5}{*}{ 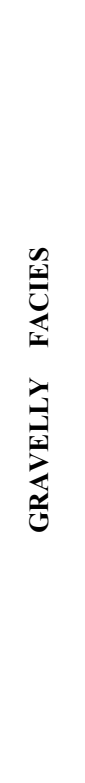 } & Gms & $\begin{array}{l}1-50 \mathrm{~cm} \\
\text { matrix supported }\end{array}$ & $\begin{array}{c}\text { Massive } \\
(*) \text { normal or inverse grading } \\
(*) \text { weak imbrication }\end{array}$ & $20-50 \mathrm{~cm}$ & Debris flow & $\begin{array}{l}\text { Feeder channel (alluvial } \\
\text { fan) }\end{array}$ \\
\hline & $\mathrm{Gmm}$ & $\begin{array}{l}\text { Granule- } 25 \mathrm{~cm} \\
\text { Clast supported } \\
(*) \text { openwork }\end{array}$ & $\begin{array}{c}(*) \text { Massive } \\
(*) \text { weak clast imbrication } \\
(*) \text { normal grading }\end{array}$ & $15-25 \mathrm{~cm}$ & $\begin{array}{c}\text { Lag } \\
\text { or } \\
\text { Braid bar head } \\
\text { construction }\end{array}$ & Channel \\
\hline & Gh & $\begin{array}{l}\text { Granule }-30 \mathrm{~cm} \\
\text { Clast supported }\end{array}$ & $\begin{array}{l}\text { Clast Imbrication } \\
\text { Grading } \\
\text { (mainly normal) } \\
\text { horizontal bedding } \\
\text { low angle planar cross } \\
\text { bedding }\end{array}$ & $20-50 \mathrm{~cm}$ & $\begin{array}{l}\text { Sheet flow } \\
\text { or } \\
\text { Braid bar head } \\
\text { construction }\end{array}$ & $\begin{array}{l}\text { Alluvial fan (medial-distal) } \\
\text { Channel (proximal-medial) }\end{array}$ \\
\hline & Gt & $\begin{array}{l}\text { Granule - pebble } \\
\text { Clast supported }\end{array}$ & Trough cross bedding & $15-25 \mathrm{~cm}$ & $\begin{array}{l}\text { Channel fill due to } \\
\text { megaripples migration }\end{array}$ & Channel (medial-distal) \\
\hline & Gmi & $\begin{array}{l}\text { Granule - pebble } \\
\text { Clast supported } \\
\text { Abundant matrix }\end{array}$ & $\begin{array}{l}\text { Clast Imbrication } \\
\text { Inverse grading }\end{array}$ & $25-40 \mathrm{~cm}$ & $\begin{array}{l}\text { Overbank near a } \\
\text { channel }\end{array}$ & $\begin{array}{l}\text { Flood plain near a channel } \\
\text { (levee, crevasse splay) }\end{array}$ \\
\hline \multirow{5}{*}{ 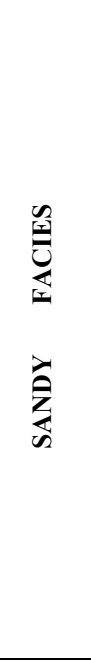 } & $\mathrm{Sm}$ & Fine-medium sand & $\begin{array}{c}\text { Massive } \\
\text { (*)floating granules \& } \\
\text { pebbles } \\
(*) \text { normal grading }\end{array}$ & $10-50 \mathrm{~cm}$ & $\begin{array}{c}\text { Overbank } \\
\text { Channel fill due to } \\
\text { waning flow }\end{array}$ & $\begin{array}{c}\text { Flood plain near a channel } \\
\text { Channel (distal) } \\
\text { Interdistributary bay }\end{array}$ \\
\hline & $\mathrm{Sp}$ & Coarse-very coarse sand & planar cross bedding & $10-40 \mathrm{~cm}$ & $\begin{array}{l}\text { Braid bar tail } \\
\text { construction }\end{array}$ & Channel (medial-distal) \\
\hline & St & Medium-coarse sand & Trough cross bedding & $10-60 \mathrm{~cm}$ & $\begin{array}{l}\text { Migration of dunes } \\
\text { and megarripples } \\
\text { Channel fill }\end{array}$ & $\begin{array}{l}\text { Distal channel } \\
\text { Secondary channel } \\
\text { (proximal) }\end{array}$ \\
\hline & So & Fine-medium sand & $\begin{array}{c}\text { Massive } \\
\text { Fe oxide } \\
\text { Rootlet traces }\end{array}$ & $30-80 \mathrm{~cm}$ & $\begin{array}{l}\text { Incipient pedogenesis } \\
\text { of sands }\end{array}$ & $\begin{array}{c}\text { Vegetated and ponded } \\
\text { floodplain } \\
\text { Inactive distributary channel } \\
\text { on delta plain }\end{array}$ \\
\hline & $\mathrm{S} 1$ & $\begin{array}{l}\text { Coarse-very coarse sand - } \\
\text { granule }\end{array}$ & $\begin{array}{l}\text { Upstream dipping low angle } \\
\text { cross bedding } \\
(*) \text { floating pebbles }\end{array}$ & $5-20-(50) \mathrm{cm}$ & Waning of sheet flow & Distal fan \\
\hline \multirow{2}{*}{ 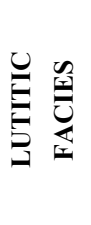 } & $\mathrm{Fl}$ & Silt-clay & $\begin{array}{c}\text { horizontal lamination } \\
\text { Uneven lamination } \\
\text { Isolated very small ripples }\end{array}$ & $20-50 \mathrm{~cm}$ & Low energy overbank & $\begin{array}{c}\text { Flood plain } \\
\text { (abandonned channel) } \\
\text { interdistributary bay }\end{array}$ \\
\hline & $\mathrm{Fr}$ & Silt-clay & $\begin{array}{l}\text { Abundant rootlet traces } \\
\text { carbonate nodules }\end{array}$ & $15-70 \mathrm{~cm}$ & $\begin{array}{l}\text { Pedogenesis on } \\
\text { overbank deposits }\end{array}$ & Flood plain \\
\hline 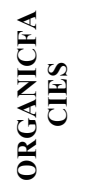 & $\mathrm{C}$ & Carbonaceous mud & $\begin{array}{c}\text { Massive } \\
\text { Plant remains }\end{array}$ & $5-25 \mathrm{~cm}$ & $\begin{array}{l}\text { Settling in stagnant } \\
\text { water }\end{array}$ & $\begin{array}{c}\text { Ponding in distal flood plain } \\
\text { interdistributary bay }\end{array}$ \\
\hline
\end{tabular}

aforementioned artificial rise in the water level obviously contributes as well to a slowing down in the decrease in the lake surface area in recent years. The lake has therefore shallowed during this phase despite the artificial rise of 120 $\mathrm{cm}$. Maximum depth, measured at the point farthest from the sediment supply of the transverse delta (next to the dam) is no more than $1.9 \mathrm{~m}$. 


\section{CONCLUDING REMARKS}

The heavy precipitation of the 2009-2010 winter has activated all the feeder systems of a small water reservoir north of the Sierra de Almijara (province of Granada, S Spain).

A comparison of the geomorphic features observed with the sedimentological facies analysis and the Ground Penetrating Radar reveals the existence of three drainage systems playing a very unequal role in the infill dynamics of this artificial lake.

The obstruction of the axial drainage evidently produces a fast, considerable change in the fluvial dynamics of a reach of the Alhama River. In a period of only eight years (19771984) it went from having a single laterally migrating braided channel to a multichannel anastomosed system with very stable channels and islands subject to a high rate of vertical accretion.

This study also reveals that the transformations in the stratal stacking pattern of a sedimentary system may be more heavily influenced by allogenic factors than by factors intrinsec to the system such as the variation in sediment supply. Thus, the modification in the accommodation space caused by the progradation and aggradation of a transverse delta fed from a highly erodible source area has cut the rate of advance of the axial delta from $100 \mathrm{~m} \mathrm{yr}^{-1}$ in the late 1970s down to zero, a rate that has held steady for the last 25 years.

This work is further proof that the construction of a dam generates a severe artificial discontinuity in the longitudinal profile that triggers noticeable transformations in the dynamics of fluvial systems. This is particularly significant in countries of the Mediterranean region, where the torrential regime of rainfall and the scanty vegetation cover facilitate the rapid siltation of the reservoirs.

The study of the sedimentary systems feeding the Alhama River reservoir reveals that rapid siltation has consequences not only on the capacity of water storage in the reservoir and its potential hydroelectric utilization, but also in the progressive alteration of the longitudinal slope of the river. This causes the consistent appearance of new wetlands and the limitation of the recreative use of the reservoir.

This example can be useful in environmental studies related to the construction of dams in countries of the Mediterranean region. Detailed analyses of the catchments that produce the most sediment and the dynamics of mass movement in the zones with different lithology within the hydrographic basin of the reservoir are crucial to prevent environmental problems. These studies become very important to delimit the zones where vegetation is needed and the most interesting points for the construction of engineered barriers for the retention of sediment.

\section{ACKNOWLEDGMENTS}

We would like to thank all the participants in the Ports and Coastal Work Group, in the Rivers and Reservoirs Work Group of the University of Granada, and participants in the Project to Study and Find Alternatives for the Use and Management of the Alhama de Granada Reservoir. This work has been funded by Research Projects. CGL2008-
05016 (MICINN-FEDER), CGL2009-07830/BTE, CGL200905768-E/BTE (MICINN), and by Research Groups RNM369 and RNM-200 of the Junta de Andalucía, to which some of the authors belong. The study has been considerably improved thanks to the suggestions of Prof. GierlowskiKordesch (Ohio University) and two anonymous reviewers. Our thanks to Christine Laurin for editing the English text.

\section{REFERENCES}

[1] C. Viseras and J. Fernández, "Sedimentary basin destruction inferred from the evolution of drainage systems in the Betic Cordillera, southern Spain,” J. Geol. Soc., vol. 149, pp. 1021-1029, 1992.

[2] B. Kostic, A. Becht, and Th. Aigner, "3-D sedimentary architecture of a Quaternary gravel delta (SW-Germany): Implications for hydrostratigraphy," Sed. Geol., vol. 181, pp. 143-171, 2005.

[3] A. Lajczak, "The role of silting and the useful lifetime of dam reservoirs in the Polish Carpatians," Z. Geomorph. N.F., vol. 38, pp. 129-150, 1994.

[4] G. Einsele and M.Hinderer, "Terrestrial sediment yield and lifetimes of reservoirs, lakes and larger basins," Geol. Rundsch., vol. 86 , no. 2 , pp. $288-310,1997$.

[5] J. Ross and R.Gilbert, "Lacustrine sedimentation in a monsoon environment: the record from Phewa Tal, middle mountain region of Nepal," Geomorphology, vol. 27, pp. 307-323, 1999.

[6] A. Palmieri, F. Shah. and A. Dinar, "Economics of reservoir sedimentation and sustainable management of dams," J. Environ. Manage, vol. 61, pp.149-163, 2001.

[7] B.K. Odhiambo and S.K. Boss, "Integrated echo sounder, GPS and GIS for reservoir sedimentation studies: examples from two Arkansas Lakes," J. Am. Water Res. Assoc., vol. 40, no. 4, pp. 981 997, 2004.

[8] V. Kapsimalis, S.E. Paulos, A.P. Karageorgis, P., Pavlakis and M. Collins, "Recent evolution of a Mediterranean deltaic coastal zone: human impacts on the Inner Thermaikos Gulf, NW Aegean Sea," J. Geol. Soc., vol. 162, pp. 897-908, 2005.

[9] M. Radoane and N. Radoane, "Dams, sediment sources and reservoir silting in Romania," Geomorphology, vol. 71, pp. 112$125,2005$.

[10] W.L Graf, "Geomorphology and American dams: The scientific, social, and economic context," Geomorphology, vol. 71, pp. 3-26, 2005.

[11] G.E. Petts and A.M. Gurnell, "Dams and geomorphology: Research progress and future directions," Geomorphology, vol . 71, pp. 2747, 2005.

[12] R.A Marston, J.D. Mills, D.R. Wrazien, B. Bassett and D.K. Splinter, "Effects of Jackson Lake Dam on the Snake River and its floodplain, Grand Teton National Park, Wyoming, USA,". Geomorphology, vol. 71, pp.79-98, 2005.

[13] M.C. Thoms, M. Southwell, and H.M. McGinness, "Floodplainriver ecosystems: Fragmentation and water resources development," Geomorphology, vol. 71, pp.126-138, 2005.

[14] G.A. Richard, P.Y. Julien, and D.C. Baird, "Statistical analysis of lateral migration of the Rio Grande, New Mexico," Geomorphology, vol. 71, pp.139-155, 2005.

[15] P.E. Grams, and J.C. Schmidt, "Equilibrium or indeterminate? Where sediment budgets fail: Sediment mass balance and adjustment of channel form, Green River downstream from Flaming Gorge Dam, Utah and Colorado," Geomorphology, vol. 71, pp.156-181, 2005.

[16] C. Viseras, J. Fernández, F. García-García, J.M. Soria, M.L. Calvache, and P. Jáuregui, "Dynamics of sedimentary environments in the accelerated siltation of a reservoir: the case of Alhama de Granada, southern Spain," Environ. Geol., 55, pp. 1353$1369,2009$.

[17] J.A Vera, "Evolution of the South Iberian Continental Margin", Mém. Mus. natn. Hist. Nat., vol. 186, pp. 109-143, 2001.

[18] J. Fernández, J.M. Soria and C. Viseras, "Stratigraphic architecture of the Neogene basins in the central sector of the Betic Cordillera (Spain): tectonic control and base level changes", In: Friend, P.F., Dabrio, C.J. Eds., Tertiary Basins of Spain: the Stratigraphic Record of Crustal Kinematics. Cambridge University Press, Cambridge, pp. 353-365. 1996. 
[19] C. Viseras, J.M. Soria, J Fernández and F. García-García, "The Neogene-Quaternary Basins of the Betic Cordillera: an overview," Geophys. Res. Abst., vol. 7, pp. 11123-11127, 2005.

[20] C. Avendaño, E. Sanz, R. Cobo and J.L. Gómez, "Sediment yield at spanish reservoirs and its relationship with the drainage basin area," In: $19^{\text {th }}$ Congress des Grands Barrages, 1997, pp. 863-874.

[21] E. Sanz, C. Avendaño, R. Cobo and J.L. Gómez, "Determination of the erosion in the Segura Basin by considering the sediment accumulated in its reservoirs," Geogaceta, vol. 23, pp. 135-138, 1998.

[22] A. Neal, N.I. Pontee, K. Pye and J. Richards, "Internal structure of mixed-sand-gravel beach deposits revealed using groundpenetrating radar," Sedimentology, vol. 49, no. 4, pp. 789-804, 2002.

[23] A. Neal, J. Richards and K. Pye, "Sedimentology of coarse-clastic beach-ridge deposits, Essex, southeast England," Sedim. Geol., vol. 162, pp. 167-198, 2003.

[24] J.L. Davis and A.P. Annan, "Ground-penetrating radar for highresolution mapping of soil and rock stratigraphy," Geophys. Prospect., vol. 37, pp. 531-551, 1989.

[25] R.L. Skelly, Ch.S. Bristow and F.G. Ethridge, "Architecture of channel-belt deposits in an aggrading shallow sandbed braided river: the lower Niobrara River, northeast Nebraska," Sedim. Geol., vol. 158 , pp. 249-270, 2003.

[26] D.G. Smith, and H.M. Jol, "Groung-penetrating radar investigation of a Lake Bonneville delta, Provo level, Bringham City, Utah," Geology, vol. 20, pp. 1083-1086, 1992.

[27] D.G. Smith, and H.M. Jol, "Radar structure of a Gilbert-type delta, Peyto Lake, Banff National Park, Canada," Sedim. Geol., vol. 113, 195-209, 1997.

[28] B.R Rust, "Depositional models for braided alluvium", Can. Soc. Petrol. Geol. Mem., vol. 5, pp. 605-626, 1978.

[29] B.J. Bluck, "Structure of coarse grained stream alluvium," Trans. R. Soc. Edimb., vol. 70, pp. 181-221, 1979.

[30] C. Viseras and J Fernández, "Channel migration patterns and related sequences in some alluvial fan systems," Sedim. Geol., vol. 88, pp. 201-217, 1994.

[31] C. Viseras and J Fernández, "The role of erosion and deposition in the construction of alluvial fan sequences in the Guadix Formation (SE Spain)," Geol. Mijnb., vol. 74, pp. 21-33, 1995.

[32] G. Postma and T.B. Roep, "Resedimented conglomerates in the bottomsets of Gilbert-type gravel deltas," J. Sedim. Petrol., vol. 55, pp. 874-885, 1985.

[33] J.M. Soria, J. Fernández, F. García-García and C. Viseras, "Correlative lowstand deltaic and shelf systems in the Guadix Basin (late Miocene, Betic cordillera, Spain): the stratigraphic record of forced and normal regressions," J. Sedim. Res., vol. 73, pp. 912-925, 2003.

[34] F. García-García, J. Fernández, C. Viseras, and J.M. Soria, "High frequency cyclicity in a vertical alternation of Gilbert-type deltas and carbonate bioconstructions in late the Tortonian, Tabernas Basin, Southern Spain," Sed. Geol., vol. 192, pp. 123-139, 2006.

[35] F. García-García, J. Fernández, C. Viseras, and J.M. Soria, "Architecture and sedimentary facies evolution in a delta stack controlled by fault growth (Betic Cordillera, southern Spain, late Tortonian)," Sed. Geol., vol. 185, pp. 79-92, 2006.

[36] C. Viseras and A Maldonado, "Facies architecture, seismic stratigraphy and development of a high-latitude basin: the Powell Basin (Antarctica)," Mar. Geol., vol. 157, pp. 69-87, 1999.

[37] U. Asprion and T. Aigner, "Towards realistic aquifer models: three-dimensional georadar surveys of Quaternary gravel deltas
(Singen Basin, SW Germany)," Sed. Geol., vol. 129, pp. 281-297, 1999.

[38] P. Huggenberger, "Radar facies recognition of facies patterns and heterogeneities within Pleistocene Rhine gravels, NE Switzerland," Geol. Soc. Spec. Publ. vol. 75, pp. 163-176, 1993.

[39] C. Ékesand, E.J. Hickin, "Ground penetrating radar facies of the paraglacial Cheekye Fan, southwestern British Columbia, Canada," Sed. Geol., vol. 143, pp. 199-217, 2001.

[40] M.L.Calvache, C. Viseras and J. Fernández, "Controls on fan development - evidence from fan morphometry and sedimentology; Sierra Nevada, SE Spain,” Geomorphology, vol. 21, pp. 69-84, 1997.

[41] C. Viseras, M.L. Calvache, J.M. Soria and J. Fernández, "Differential features of alluvial fans controlled by tectonic or eustatic accommodation space", Examples from the Betic Cordillera, Spain, Geomorphology, vol. 50, pp. 181-202, 2003.

[42] L.H. Blirka and W. Nemec, "Postglacial colluvium in western Norway: depositional processes, facies and palaeoclimatic record," Sedimentology, vol. 45, pp. 909-959, 1998.

[43] A. Amorosi, M.L. Colalongo, G., Pasini and D. Preti, "Sedimentary response to Late Quaternary sea-level changes in the Romagna Coastal Plain (northern Italy)," Sedimentology, vol. 46, pp. 99-121, 1999.

[44] I.A. Lunt and J.S. Bridge, "Evolution and deposits of a gravely braid bar, Sagavanirktok River, Alaska," Sedimentology, vol. 51, pp. 415-432, 2004.

[45] C. Viseras, J.M. Soria, J.J. Durán, S. Pla, G. Garrido, F. GarcíaGarcía and A., Arribas, "A large-mammal site in a meandering fluvial context (Fonelas P-1, Late Pliocene, Guadix Basin, Spain). Sedimentological keys for its paleoenvironmental reconstruction," Palaeogeogr., Palaeoclimatol., Palaeoecol., vol. 242, pp. 139-168, 2006.

[46] G.H.S. Smith, P.J. Ashworth, J.L. Best, J. Woodward and C.J. Simpson, "The sedimentology and alluvial architecture of a sandy braided South Saskatchewan River, Canada," Sedimentology, vol. 53, pp. 413-434, 2006.

[47] A. Amorosi, M.L. Colalongo, F. Fusco, G. Pasini and F. Foirini, "Glacio-eustatic control of continental - shallow marine cyclicity from late Quaternary deposits of the southeastern Po Plain, Northern Italy", Quatern. Res., vol. 52, pp. 1-13. 1999.

[48] T.C. Blair and J.G McPherson, "Alluvial fans and its natural distinction from rivers based on morphology, hydraulic processes, sedimentary processes and facies assemblages", J. Sedim. Res., vol. 64, no. 3, pp. 450-489, 1994.

[49] S. Pla-Pueyo, E.H. Gierlowski-Kordesch, C. Viseras and J.M Soria, "Major controls on carbonate deposition during the evolution of a continental basin: Pliocene-Pleistocene of the Guadix Basin (Betic Cordillera, southern Spain)," Sed. Geol., vol. 219, pp. 97114, 2009.

[50] T. Muto and R.J. Steel, "Principles of regression and transgression: the nature of the interplay between accommodation and sediment supply,” J. Sedim. Res., vol. 67, pp. 497-505, 1997.

[51] T. Muto and R.J. Steel, "The accommodation concept in sequence stratigraphy: some dimensional problems and possible redefinition," Sed. Geol., Vol. 130, pp. 1-10, 2000.

[52] J. Fernández, B.J. Bluck and C. Viseras, "The effects of fluctuating base level on the structure of alluvial fan and associated fan delta deposits: an example from the Tertiary of the Betic Cordillera, Spain," Sedimentology, vol. 40, pp. 879-893. 1993.

This is an open access article licensed under the terms of the Creative Commons Attribution Non-Commercial License (http://creativecommons.org/licenses/by-nc/ 3.0/) which permits unrestricted, non-commercial use, distribution and reproduction in any medium, provided the work is properly cited. 